\title{
Pseudolillia Maubeuge, 1949 (Ammonitida, Hildoceratidae) in the Lower Jurassic (Toarcian) of the NE Spain
}

\author{
Miguel MORATILLA-GARCÍA ${ }^{1}$, Antonio GOY²* \& María José COMAS-RENGIFO² \\ ${ }^{1}$ Jesús García Perdices, nº 3, 4º, 19004 Guadalajara, Spain; miguel.moratilla@gmail.com \\ ${ }^{2}$ Departamento de Paleontología, Facultad de Ciencias Geológicas, Universidad Complutense de Madrid, José Antonio Novais, \\ 12,28040 Madrid, Spain; angoy@ucm.es; mjcomas@ucm.es \\ * Corresponding author
}

Moratilla-García, M., Goy, A. \& Comas-Rengifo, M.J. 2017. Pseudolillia Maubeuge, 1949 (Ammonitida, Hildoceratidae) in the Lower Jurassic (Toarcian) of the NE Spain. [Pseudolillia Maubeuge, 1949 (Ammonitida, Hildoceratidae) en el Jurásico Inferior (Toarciense) del NE de España]. Spanish Journal of Palaeontology, 32 (1), 147-170.

\section{ABSTRACT}

In the present paper, 147 specimens assigned to the genus Pseudolillia Maubeuge, 1949 are studied. This is a considerably high number of samples in comparison with those known in other geographical areas where they have been cited, such as northern France, the Pyrenees, the Betic Range, Morocco, Portugal, Italy, Hungary and Bulgaria. The six taxa described, $P$. murvillensis, $P$. hispanica, . emiliana, P. donovani, Pseudolillia ? n. sp. (en García-Gómez \& Rivas, 1980), and Pseudolillia ? sp., come from 22 sites in the Cantabrian and Iberian Ranges and the Isle of Majorca. Their presence in expanded sections enabled us to situate the stratigraphic position of the genus between the upper part of the Thouarsense Chronozone (Fallaciosum Subchronozone) to the Dispansum Chronozone (Gruneri Subchronozone), with maximum abundance found in the Dispansum Chronozone (Insigne Subchronozone). The origin of the genus is unclear, and a possible derivation from the last representatives of Grammoceras (close to G. striatulum) or more likely from Esericeras (close to E. fascigerum) has been suggested. The known palaeobiogeographic range of Pseudolillia is limited to the NW-European Province and to the W of the Tethys, and with the exception of $P$. emiliana, the species' distribution ranges are short. In NE Spain, where the highest number

\section{RESUMEN}

Se han estudiado 147 ejemplares asignados al género Pseudolillia Maubeuge, 1949, lo que es un número considerablemente elevado si se compara con los conocidos en otras áreas geográficas donde han sido citados, como el norte y centro de Francia, los Pirineos, la Cordillera Bética, Marruecos, Portugal, Italia, Hungría y Bulgaria. Proceden de un total de 22 localidades de las cordilleras Cantábrica, Ibérica, Isla de Mallorca y Pirineos. Se han descrito seis taxones: P. murvillensis, P. hispanica, P. emiliana, P. donovani, Pseudolillia ? n. sp. (en García-Gómez \& Rivas, 1980) y Pseudolillia? sp. Su presencia en secciones expandidas, ha permitido situar la posición estratigráfica del género desde la parte alta de la Cronozona Thouarsense (Subcronozona Fallaciosum) hasta la Cronozona Dispansum (Subcronozona Gruneri), encontrándose la máxima abundancia en la Cronozona Dispansum (Subcronozanona Insigne). El origen del género no es del todo claro, y ha sido sugerida una posible derivación de miembros tardíos de Grammoceras (próximos a G. striatulum) o más probablemente de Esericeras (próximos a E. fascigerum). La distribución paleobiogeográfica conocida de Pseudolillia se limita a la provincia NO-Europea y a la parte $\mathrm{O}$ del Tethys y, con excepción de $P$. emiliana, las áreas de distribución de las especies son relativamente pequeñas. 
of known specimens comes from, $P$. donovani (typical of the Mediterranean province) is the species presenting the oldest record (Chronozone Thouarsense, Subchronozone Fallaciosum), although it did not necessarily live and reproduce in very nearby areas. P. murvillensis (typical of the NW-European Province), was found in the Chronozone Dispansum (Subchronozone Insigne) together with $P$. emiliana and $P$. hispanica in the eastern Pyrenees and particularly in the central sector of the Iberian Range.

Keywords: Upper Toarcian, Grammoceratinae, taxonomy, palaeobiogeography, Iberian Peninsula.
En el NE de España, de donde proceden el mayor número de especímenes conocidos, $P$. donovani (típica de la Provincia Mediterránea) es la especie que tiene un registro más antiguo (Cronozona Thouarsense, Subcronozona Fallaciosum), aunque se supone que no necesariamente vivía y se reproducía en áreas muy cercanas. P. murvillensis (típica de la Provincia NO-Europea), ha sido encontrada en la Cronozona Dispansum (Subcronozona Insigne) junto con P. emiliana y P. hispanica en los Pirineos orientales y, sobre todo, en el sector central de la Cordillera Ibérica.

Palabras clave: Toarciense superior, Grammoceratinae, taxonomía, paleobiogeografía, Península Ibérica.

\section{INTRODUCTION}

The genus Pseudolillia Maubeuge, 1949, from the upper Toarcian in Europe and the $\mathrm{N}$ of Africa, extends mainly from Lorraine, in the NE of France, to the Atlas Mountains in Morocco, with some occasional references in Alpine areas. The record tends to be scarce or very scarce in most of the sites where it has been cited, and it is the Iberian Peninsula, especially in the central sector of the Iberian Range, where most of the known specimens were found. In the present paper we study the available material of the species of the genus Pseudolillia recorded in the outcrops of the upper Toarcian in the E and $\mathrm{N}$ of Spain. We attempt to conduct a systematic classification and to specify the precise stratigraphic position of the species. Our research also aims to establish the palaeobiogeographic distribution of each of them. We paid particular attention to the Iberian Range, collecting new samples in its central sector, especially in the localities of Ribarredonda, Huertahernando, Villar de Cobeta, Buenafuente del Sistal and Turmiel in the province of Guadalajara, and in the Rambla del Salto and Ariño in the province of Teruel. Also included in the present research are the specimens identified by previous authors, some specimens from the collection of the Geominero Museum (IGME) and from the Asturias Jurassic Museum (MUJA) and those from the Isle of Majorca (Álvaro et al., 1989) and from the Cantabrian Range (Suárez Vega, 1974; Bernad, 1992, 1993; Goy et al., 1994, 2010).

The genus Pseudolillia was created by Maubeuge (1949) based upon one single specimen found in Murville Mine (Meurtheet Moselle, Lorraine, France), which was called Pseudolillia murvillensis. This author included Pseudolillia in the Subfamily Phymatoceratinae, as would later be done by Arkell et al. (1957). Donovan (1962) revised the genus and included therein the species Ammonites emilianus, described by Reynès (1868), which he provisionally incorporated into the Subfamily
Grammoceratinae. Subsequently, García-Gómez \& Rivas (1980) and Elmi \& Rulleau (1990), based upon the new species recognised, also emended the genus. These authors, along with Howarth (2013) maintained Pseudolillia within Grammoceratinae.

García-Gómez \& Rivas (1980) studied the genus in the Betic Range and described two new species, Pseudolillia donovani, Pseudolillia ? n. sp., and one new subspecies, Pseudolillia murvillensis hispanica. Moreover, they extended the information on the diagnosis of the genus and on the species P. emiliana. In their opinion, the ribbing is not always straight on the flank, but can present a sinusoidal trajectory similar to that of Pseudogrammoceras. In relation to the coiling, although Maubeuge (1949) considered that the umbilicus undergoes a relative decrease in size during ontogeny, he pointed out that this occurs in some species, but not in others such as $P$. donovani. Furthermore, the shape of the section can also show no variation during ontogeny. The abovementioned authors suggested that this genus presents close affinities with Esericeras, and it is therefore related with Grammoceratinae, in accordance with the opinion of Donovan (1962).

Elmi \& Rulleau (1990) conducted a revision of the genus Pseudolillia in south-western Europe and Morocco, which comprises all the species on our research. They described and identified important material from the quarries of Lafargue in Belmont (Bas Beaujolais, Rhône, France), together with some specimens from Morocco, the Betic Range and the Iberian Range. They also considered highly likely that this genus belongs to the Grammoceratinae.

Sassaroli \& Venturi (2005) described a new species, Pseudolillia apenninica, based on one single specimen found in levels of the Bonarelli Zone in the Marconessa Quarry (Cingoli, Central Appenines, Italia). Metodiev (2008) studied the genus Pseudolillia in several localities of the $\mathrm{W}$ of Bulgaria and cited it as coming from levels of the Fallaciosum Zone of the Bulgarian scale (= Thouarsense 
Zone, Fallaciosum Subzone of the standard scale). Kovács (2013), in his study on the Grammoceratinae of the Gerecse Mountains (Hungary) described a new species of Pseudolillia, P. paralleliformis, from the lower part of the Speciosum Zone.

In addition, in the $\mathrm{N}$ and $\mathrm{E}$ of the Iberian Peninsula, this genus has been cited in general studies, among others, by Suárez Vega (1974), Bernad (1992, 1993) and Goy et al. (1994, 2010), in the Cantabrian Range; Fauré (2002), in the eastern Pyrenees; Goy (1974), Comas-Rengifo (1974), Mouterde et al. (1978), Comas-Rengifo \& Goy (1978), Goy et al. (1988), Elmi et al. (1989), Goy \& Martínez (1990), Goy et al. (1996) and Comas-Rengifo et al. (1996) in the Iberian Range. Outside the study area, the genus has also been cited by Mouterde et al. (1998) and Elmi et al.
(2007) in the Lusitanian Basin (Portugal), García-Gómez \& Rivas (1980) in the $\mathrm{S}$ of el Zegrí and Cerro Méndez (Granada) and Caracuel et al. (2004) in Cerro de la Cruz (Sierra de Reclot Alicante).

\section{STRATIGRAPHIC CONTEXT}

The specimens employed in the present research are from the Cantabrian and Iberian Ranges and the Isle of Majorca (Fig. 1). Moreover, we took into consideration those that were figured by other authors from the Betic and Iberian Ranges and the Pyrenees (García-Gómez \& Rivas, 1980; Elmi \& Rulleau, 1990; Fauré, 2002). In the Cantabrian

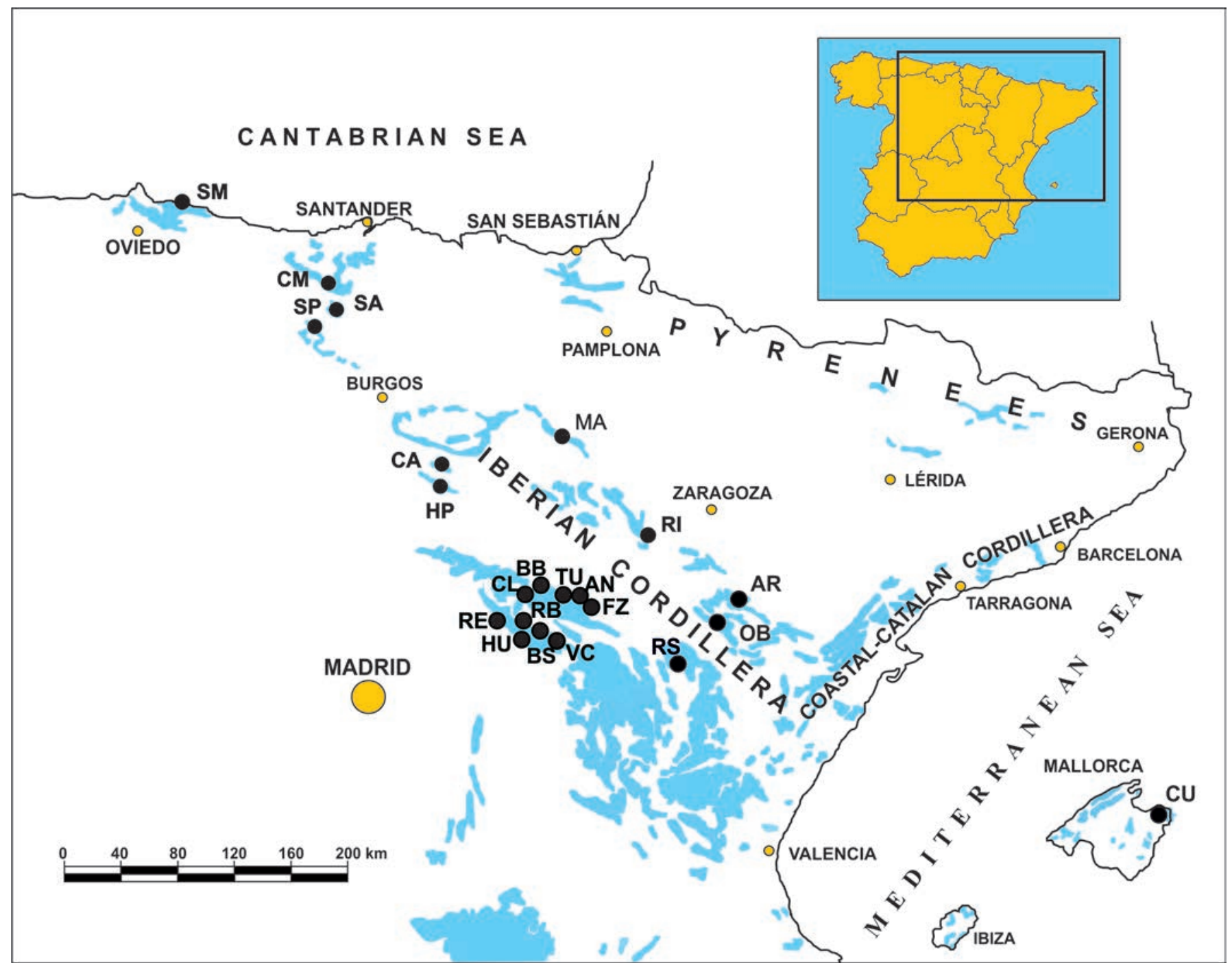

Figure 1. Geographical location of sections and/or localties where specimens of the genus Pseudolillia have been found. SM: Santa Mera; CM: Camino; SA: San Andrés; SP: Salinas de Pisuerga; MA: Muro de Aguas; CA: Castrovido; HP: Hontoria del Pinar; RI: Ricla; AR: Ariño; OB: Obón; RS: Rambla del Salto; BB: Balbacil; CL: Clares; FZ: Fuentelsaz; AN: Anchuela del Campo; TU: Turmiel; RE: Renales; RB: Ribarredonda; HU: Huertahernando; BS: Buenafuente del Sistal; VC: Villar de Cobeta; CU: Puig de Cutri. 
Range, representatives of the genus Pseudolillia have been obtained in Santa Mera (Asturias), Camino and San Andrés (Cantabria) and in Salinas de Pisuerga (Palencia); in the Iberian Range in Muro de Aguas (Logroño), Castrovido and Hontoria del Pinar (Burgos), Ricla (Zaragoza), Ariño, Obón and la Rambla del Salto (Teruel), Balbacil, Clares, Fuentelsaz, Anchuela del Campo, Turmiel, Renales, Ribarredonda, Huertahernando, Buenafuente del Sistal and Villar de Cobeta (Guadalajara); and on the Isle of Majorca in el Puig de Cutri, in the Serra de Llevant.

The lithostratigraphic units where the studied specimens come from generally comprise alternations of limestone and marls in the Cantabrian and Iberian Ranges, which correspond to the Castillo Pedroso (Robles et al., 2003) and Turmiel (Goy et al., 1976) formations, respectively. In el Puig de Cutri, they were found in a small section with ferruginous oolites containing numerous reelaborated ammonites, which is situated at the base of the Gorg Blau Formation (Álvaro et al., 1984, 1989). The sections located in the Cantabrian and Iberian Ranges are generally expanded and exhibit few significant discontinuities in the interval corresponding to the upper Toarcian. The specimens of Pseudolillia are recorded in the transgressive part of the T-R LJ-4 cycle defined by Gómez \& Goy (2004, 2005), which corresponds to one of the episodes of greatest relative depth of the Toarcian in both mountain ranges.

The scales of reference employed in the present research for the considered interval (Fig. 2) are those proposed by Elmi et al. $(1994,1997)$ and Page (2003) for the NW-Europe and Mediterranean Provinces. The Figure 3 shows the stratigraphic distribution of the species identified in the most significant sections of the areas studied. The columns represent the sediments of the Thouarense p.p. and Dispansum Zones, according to different authors.
It should be pointed out that in this figure, we have adapted the scales used in studies prior to that proposed by Elmi et al. (1997) in order to include the Fallaciosum Subzone, traditionally considered as a part of the Insigne Zone (equivalent to the Dispansum Zone), as a part of the Thouarsense Zone.

\section{MATERIAL AND METHODS}

To study the genus Pseudolillia in the NE of Spain, we analysed a total of 147 specimens from 22 localities. They corresponded to several collections deposited in Department of Palaeontology of Madrid's Complutense University (UCM), to specimens from the collections of the Geominero Museum (IGME) and of the Asturias Jurassic Museum (MUJA). Furthermore, we used specimens from the Cantabrian Range (Suárez Vega, 1974; Bernad, 1992, 1993; Goy et al., 1994, 2010), from the $\mathrm{E}$ of the Isle of Majorca (Álvaro et al., 1989), and from different samples collected since 2013 for the purposes of the present study. Eight of them were found in the Cantabrian Range, 4 in the north of the Iberian Range, 129 in the central Iberian Range and 6 in the Serra de Llevant (Isle of Majorca). Eight specimens, in all cases attributed to Pseudolillia emiliana (Reynès), had previously been figured by different authors.

Due to the different origins of the material, the format of the acronyms is different. The acronym used is divided into three parts: a) initials in capital letters for the site of origin; if there were to exist more than one section in this site, one number more is added; $b$ ) the number of the set from which the material was collected; if it is a layer, a letter can be added ("i" o " $\mathrm{s}$ ") to indicate the relative

\begin{tabular}{|c|c|c|c|}
\hline \multicolumn{2}{|c|}{ NW-European Province } & \multicolumn{2}{|c|}{ Mediterranean Province } \\
\hline Subzone & Zone & Zone & Subzone \\
\hline \multicolumn{2}{|c|}{ ? } & \\
\hline Pseudoradiosa & \multirow{2}{*}{ Pseudoradiosa } & \multirow{2}{*}{ Meneghinii } & \\
\hline Levesquei & & & \\
\hline Gruneri & \multirow{2}{*}{ Dispansum } & \multirow{2}{*}{ Speciosum } & Reynesi \\
\hline Insigne & & & Speciosum \\
\hline Fallaciosum & & & Fallaciosum \\
\hline Fascigerum & \multirow{3}{*}{ Thouarsense } & \multirow{3}{*}{ Bonarelli } & \multirow{3}{*}{ Mediterraneum } \\
\hline Thouarsense & & & \\
\hline Bingmanni & & & \\
\hline
\end{tabular}

Figure 2. Upper Toarcian standard scale (Thouarsense, Dispansum y Pseudoradiosa Zones) in the NW-European and Mediterranean Provinces according to Elmi et al. (1997). The colored area corresponds to the time interval in which there have been identified specimens of Pseudolillia. 


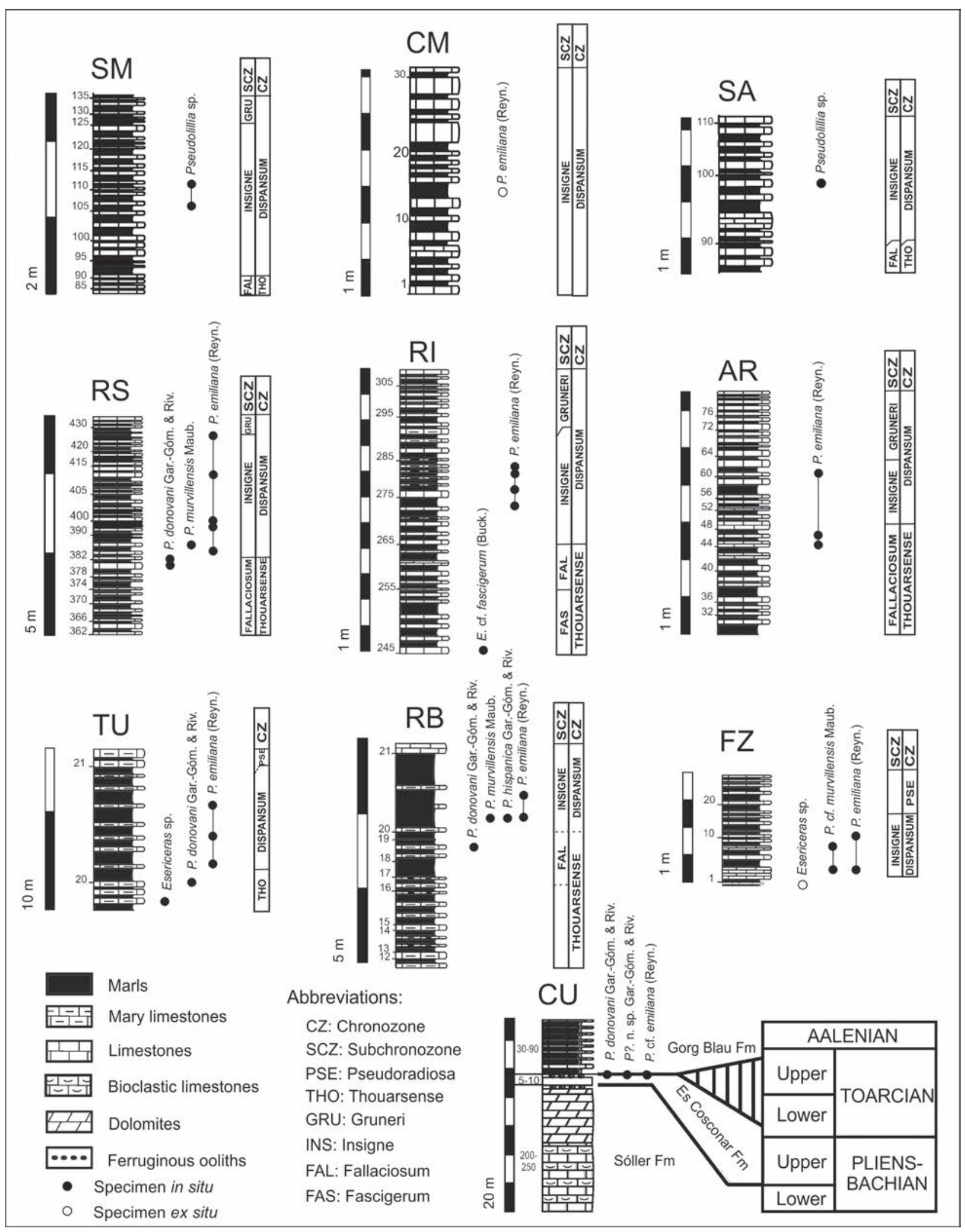

Figure 3. Main reference sections of the interval studied indicating the position of the specimens of the genus Pseudolillia. SM (cf. Goy et al., 2010); CM and SA (modified after Goy et al., 1994); RS (cf. Comas-Rengifo et al., 1996); RI (modified after Goy \& Martínez, 1990); AR (cf. Martínez, 2007); TU (new section); RB (cf. Comas-Rengifo \& Goy, 1975); FZ (modified after Martínez, 1992); CU (modified after Goy et al., 1995). Abbreviations as in the Figure 1. 
position within the set; c) number of the specimen collected in one level or set in the same site.

The dimensions of the specimens we were able to measure are limited in most cases to whorl height $(\mathrm{H})$ and to thickness (E); in very few specimens we were able to measure the diameter of the shell (D) or the width of the umbilicus (O). Additionally, we performed the relations $\mathrm{E} / \mathrm{H}$ and $\mathrm{O} / \mathrm{D}$ in order to more easily compare these values.

Conservation of the available remains of the different specimens of Pseudolillia has meant that we basically conducted the study and differentiation of the taxa bearing in mind the variability of the cross sections, changes in ornamentation and relative umbilicus width during the ontogenic development, as these are the features that are easiest to observe in the fragmented specimens.

To describe the taxa we followed the nomenclature employed in the Treatise on Invertebrate Paleontology (Arkell et al, 1957; Howarth, 2013). Furthermore, in the description of the taxa we used one single scheme, structured into three paragraphs: a) shape of the shell, referring to the characters described by the morphology following a specific order (coil, whorl section, umbilicus and umbilical wall); b) ornamentation, pointing out whether specimens attributed to a given taxon display it and, if this is the case, type and development throughout ontogeny; c) suture line, describing it according to its elements.

The specimens are internal moulds reflecting the exterior ornamentation. Most of them are incomplete phragmocones, and exceptionally, a part of the body chamber can be observed (Figs 6, 11). This is to say, we had no complete individuals available.

Specimens frequently present evidence of resedimentation, such as the existence of epizoans (ostreids, serpulids and bryozooans) on the mould. In some cases, as occurs with the specimens from the Puig de Cutri section (Figs 10.5-10.7), we identified manganese crusting, as well as the presence of abrasion on the moulds, which indicate reelaboration of these remains (FernándezLópez, 2000). Quite often, the internal whorls have not been completely filled in with sediment; calcite therefore precipitated on the inside. We also identified frequent fossil-diagenetic distortion processes such as deformation of the whorls and the presence of fissures and fractures in the mould. We also recognised examples of corrosion on the moulds, which was caused by the action of erosion following exhumation of the specimens.

The fact that most of the ammonites studied are largesized and that in the small ones we were unable to observe clear signs of initiation of the body chamber, favours the hypothesis that almost all the specimens are adults and preadults. Practically all fit within the type 3 or 2 associations sensu Fernández-López (1985), and it is therefore likely that many of the specimens studied did not live in the area from where they were collected, but rather came from more or less distant regions.

\section{SYSTEMATICS}

\section{Family Hildoceratidae Hyatt, 1867}

Subfamily Grammoceratinae Buckman, 1905

According to Howarth (2013) this subfamily includes generally involute forms with straight or somewhat curved ribbing deriving from the Hildoceratinae, and giving rise to more involute forms. The outer whorls can become smooth. It presents marked dimorphism in some genera and for the first time, long lappets appear on the peristomes of the adult microconches. The geographic range is worldwide and the stratigraphic distribution ranges from the Lower Jurassic (upper Toarcian, Variabilis Zone) to the Middle Jurassic (Aaleniense, Opalinum Zone).

\section{Genus Pseudolillia Maubeuge, 1949, p. 150}

This genus is characterised by presenting moderately evolute inner whorls, with a subquadrate cross section with a keel and marked grooves in the ventral region. The ribbing is simple and straight on the flank, but becomes curved on reaching the ventral region. The outer whorls become smooth and more involute. The whorl section becomes convergent or triangular, without grooves (Donovan, 1962). To this description, also given by Howarth (2013), the nuances described by García-Gómez \& Rivas (1980) regarding the size of the umbilicus during ontogeny must be added. Both Maubeuge (1949) and Donovan (1962) claim that the umbilicus becomes smaller with growth, but this is not the case of the Pseudolillia donovani García-Gómez \& Rivas, which maintains an evolute coiling.

\section{Pseudolillia murvillensis Maubeuge, 1949}

(Figs 4a-b, Figs 5.1-5.3, Fig. 11.1)

1949 Pseudolillia murvillensis n. sp. Maubeuge, p. 150, Pl. 1, fig. 1; Pl. 2, fig. 1.

1962 Pseudolillia murvillensis, Donovan, p. 86-90, Pl. 12, figs. 3, 4 (refigured of the holotype) (non Pl. 12, figs. 1-2).

1990 Pseudolillia murvillensis, Elmi \& Rulleau, p. 295, Pl. 1, fig. 3; Pl. 2, figs. 1-4; Pl. 4, figs. 3-4.

? 2002 Pseudolillia sp. aff. murvillensis Maubeuge, Fauré, p. 725, Pl. 20, figs. 9a, 9b.

Material. MUJA-2105 (in Suárez Vega, 1974, p. 74), RS.386/1; BB.5.5i/1; FZ.1/2; FZ.7/1; TU3.5.5i/11 (cf.); RE.5.5i/1, 2 (cf.), 4; RB.C20/1 (cf.), 9 (cf.); HU.5.5i/1 (cf.), 2 (cf.), 3, 4 (cf.), 15 (cf.); VC.5.5i(+1.2 m base)/4, 5,9 (cf.).

Measurements are shown in Table 1. 
Table 1. P. murvillensis.

\begin{tabular}{llcccccc}
\hline ACRONYM & \multicolumn{1}{c}{ SPECIES } & D & O & O/D & H & E & E/H \\
\hline RS.386/1 & P. cf. murvillensis & - & - & - & 19.91 & 17.10 & 0.86 \\
BB.5.5i $/ 1$ & P. murvillensis & - & - & - & 64.75 & 36.30 & 0.56 \\
FZ.1/2 & P. murvillensis & 102.1 & 29.5 & 0.29 & 38.70 & 23.50 & 0.61 \\
FZ.7/1 & P. murvillensis & - & - & - & 20.80 & 14.37 & 0.69 \\
RE.5.5i/1 & P. murvillensis & - & - & - & 20.79 & 14.10 & 0.68 \\
RE.5.5i/4 & P. murvillensis & - & - & - & 43.13 & 32.07 & 0.74 \\
HU.5.5i/3 & P. murvillensis & - & - & - & 56.41 & 32.09 & 0.57 \\
HU.5.5i $/ 15$ & P. cf. murvillensis & - & - & - & 26.48 & 16.49 & 0.62 \\
VC.5.5i $(+1,2) / 9$ & P. cf. murvillensis & - & - & - & 72.40 & 46.92 & 0.65 \\
\hline
\end{tabular}

Description. Shells presenting a moderately involute coiling. The whorl section is wide and generally subtrapezoidal, with the maximum width on the umbilical edge (Figs 4A-4B). The keel is wide and is flanked by two well-marked grooves in young individuals, which tend to disappear throughout ontogeny, becoming two flat areas at the end of the phragmocone in adult individuals. The umbilicus is relatively small and deep, with a high and vertical umbilical wall.

The ornamentation comprises thick, slightly sinuous ribs, curving sharply forward onto the peristome in the ventral zone. These do not reach the keel, and may die out on the outer whorls as they disappear into the grooves. In the first whorls the ribbing is similar, but density decreases throughout ontogenic development, practically disappearing for whorl heights greater than $40 \mathrm{~mm}$.

The suture line is relatively simple; the first lateral saddle is notably wide and bifid, followed by a broad lateral lobe. The second lateral saddle presents varying degrees of definition and the first suspensive lobe is narrow.

Remarks. Although it is the type species of the genus, it is not the most abundant one in the localities studied or in any of the sites where it has been recognised, because $P$. emiliana tends to be much more frequent in all the regions where both species have been cited. P. murvillensis can easily be differentiated from $P$. emiliana due to its thicker whorl, particularly in the adult stage, and to its subtrapezoidal section and higher vertical umbilical wall. Differentiation is more difficult in early stages, since the internal whorls are very similar.

The specimens classified as $P$. cf. murvillensis correspond to fractured ones in which it is difficult to observe the characters (RB.C20/1, Fig. 5.2), or to inner whorls of specimens difficult to differentiate from other species (RS.386/1, Fig. 5.3).

The specimen (HU.5.5i/3, Fig. 11.1) shows a part of the body chamber. It is flattened, lacks ornamentation and, in the ventral zone has a thick keel flanked by two smooth areas.
Geographic and stratigraphic distribution. $P$. murvillensis has been cited in France, where it is known in Murville (Meurthe et Mosselle, Lorraine) and in Belmont (Bas-Beaujolais, Rhône). In the NE of Spain it is known in the Iberian Range, where it has been identified in 8 localities: Rambla del Salto, Balbacil, Fuentelsaz, Turmiel, Renales, Ribarredonda, Huertahernando, Villar de Cobeta and in the eastern Pyrenees, where it was cited by Faure (2002, p. 725, Pl. 20, figs. 9a, 9b) from Coll de Port, S of Tuixén (Pedraforca).

Furthermore, Donovan (1962) refers to a specimen from the Betic Range, which García-Gómez \& Rivas (1980) subsequently assigned to $P$. murvillensis hispanica.

The stratigraphic distribution of this taxon in the NE of Spain is restricted to the Dispansum Chronozone (Insigne Subchronozone).

\section{Pseudolillia hispanica García-Gómez \& Rivas, 1980 (Fig. 4C, Fig. 6, Figs 7.1-7.2)}

1962 Pseudolillia murvillensis Maubeuge - Donovan, Pl. 12, Text-figs. 1-2, figs. 1a-1b.

1980 Pseudolillia murvillensis hispanica n. s.sp. García-Gómez \& Rivas, p. 198, Pl. 1, figs. 3-4.

Material. TU4.5.5i/11 (cf.); AN.567J; RB.5.5i/1, 6 (cf.), 7; RB.C20/5 (cf.), 8 (cf).

All measurements are shown in Table 2.

Tabla 2. P. hispanica.

\begin{tabular}{llcccccc}
\hline ACRONYM & SPECIES & D & O & O/D & H & E & E/H \\
\hline AN.567J & P. hispanica & 90.91 & 24.34 & 0.27 & 40.08 & 20.00 & 0.50 \\
RB.5.5i/1 & P. hispanica & - & - & - & 55.31 & 25.95 & 0.47 \\
RB.5.5i/6 & P. cf. hispanica & - & - & - & 21.66 & 12.3 & 0.57 \\
RB.5.5i/7 & P. hispanica & 100.20 & 30.50 & 0.29 & 40.15 & 20.25 & 50.00 \\
RB.C20/5 & P. cf. hispanica & - & - & - & 31.47 & 17.61 & 0.56 \\
\hline
\end{tabular}

Description. Shells displaying a moderately involute whorl. The whorl section is high, narrow and subtriangular, with the greatest thickness close to the umbilical contour. The keel is wide and flanked by two flat areas, which in inner whorls constitute grooves. The umbilicus is small and the walls are high and vertical.

It presents ornamentation in the form of straight or slightly sinuous ribs curving sharply towards the peristome in the ventral zone, but do not reach the keel. Density diminishes during ontogeny, practically disappearing for whorl heights of around $30 \mathrm{~mm}$.

The suture line can clearly be observed in the specimen RB.5.5s/1 (Fig. 7.1). It comprises a narrow saddle and ventral lobe, followed by a first lateral saddle, which is wider and bifid. The lateral lobe and the second lateral saddle are cropped. The suspensive lobe is narrow. 


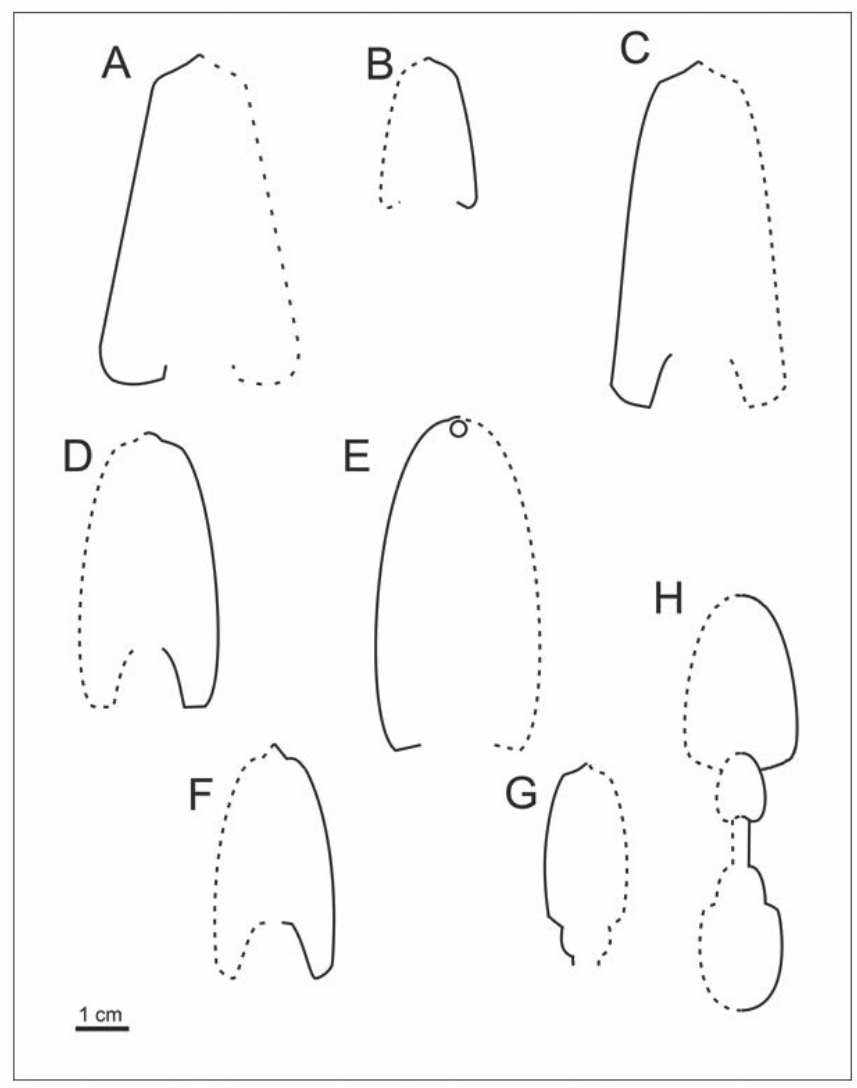

Figure 4. Whorl section of different specimens of Pseudolillia. A) P. murvillensis (BB.5.5i/1). B) P. cf. murvillensis (HU.5.5i/15). C) P. hispanica (RB.5.5i/1). D) $P$. emiliana (RS.394/4). E) P. emiliana (TU2.5.5i/1). F) P. emiliana (TU3.5.5i/4). G) P. donovani (TU3.5.4s/8). H) Pseudolillia? sp. (CU.11/3). The solid line corresponds to the best-conserved flank.

Remarks. This species was originally described by García-Gómez \& Rivas (1980) as a subspecies of P. murvillensis. Subsequently, Elmi \& Rulleau (1990) included it in the synonymy of $P$. murvillensis, explaining that it occupies an intermediate position between this species and $P$. emiliana. In the present paper, it has been considered as a separate species, since specimens have been found in different localities of the Betic and the Iberian Ranges and because no data exist to confirm that it is a geographical variation of $P$. murvillensis. Moreover, the clearly narrower whorl section, the umbilicus, which is wider than that of P. murvillensis, and the oblique and not vertical umbilical wall constitute differences which distinguish it from P. murvillensis.

The main feature of $P$. murvillensis involves its whorl section, as can be seen in the $\mathrm{E} / \mathrm{H}$ ratio. This is lower in $P$. hispanica, as the whorl height is greater and the whorl section is less thick. As for P. emiliana, it is differentiated by its subtriangular whorl section towards the end of the phragmocone in adult specimens.
The specimen from Anchuela del Campo (AN-567J) held at Geominero Museum (IGME) was classified as $P$. cf. murvillensis. As Figure 7.2 shows, the whorl section is high and subtriangular, and it has therefore been included in $P$. hispanica.

Geographic and stratigraphic distribution. The specimens studied were collected in the Iberian Range in the Anchuela del Campo, Turmiel and Ribarredonda sections. The ones cited by other authors are from Zegrí Sur (Granada) (García-Gómez\& Rivas, 1980).

The specimens from Ribarredonda correspond to the Dispansum Chronozone (Insigne Subchronozone). Those from el Zegrí are located in "ammonitico rosso" facies presumably condensed, whose biostratigraphic position, according to García-Gómez \& Rivas (1980), is defined by the position of the last morphology of Pseudogrammoceras of the group of $P$. fallaciosum (Bayle).

Pseudolillia emiliana (Reynès, 1868)

(Figs 4D-4F, Fig. 7.3, Fig. 8, Fig. 9)

1868 Ammonites emilianus n. sp. Rèynes, p. 104, Pl. 6, figs. 1a-c.

1921 Hildoceras emilianum, Monestier, p. 22, Pl. 1, figs. 14-16; P1. 4, fig. 23.

1962 Pseudolillia emiliana, Donovan, p. 90, Text-fig. 2c, d.

1974 Pseudolillia emiliana, Goy, p. 688, Pl., 83, fig. 2.

1974 Pseudolillia sp. A, Goy, p. 688, Pl. 83, fig. 1.

?1974 Pseudolillia sp. B, Goy, p. 689, Pl. 83, fig. 3.

1974 Pseudolillia emiliana, Comas-Rengifo, Pl. 20, figs. 2-5.

1975 Pseudolillia emiliana, Guex, p. 107, P1. 8, figs. 6-7.

1977 Pseudolillia emiliana, Ureta, Pl. 1, fig. 2.

1980 Pseudolillia emiliana, García-Gómez \& Rivas, p. 196, Pl. 3, fig. 2.

1986 Pseudolillia emiliana, Martínez, p. 114, Pl. 10, fig. 2.

1990 Pseudolillia emiliana, Elmi \& Rulleau, p. 297, Pl. 1, figs. 4, 5; Pl. 3, figs. 1-4; Pl. 4, figs. 1, 2; Pl. 5, figs. 1-4; Pl. 6, figs. 1-4; Pl. 7, figs. 5-8.

1993 Pseudolillia sp. [cf. P. emiliana (Rèynes)], Bernard, p. 121, Pl. 2, fig. 28.

2008 Pseudolillia emiliana, Metodiev, figs. 6, c, d?

2013 Pseudolillia emiliana, Kovács, p. 130, Pl. 4, fig. 3.

Material. CM. 13/1, 2; SP.1/5 (cf.) (in Bernad, 1993, Pl. 3, fig. 28); 1MA.305/1 (cf.); 4CV.154/1 (in ComasRengifo et al., 1988, p. 127); HP.4/1 (in Ureta, 1977, Pl. 1, fig. 2); RI.273/1, 275/1 (in Martínez, 1986, Pl. 10, fig. 2), 277/1, 279/1; 4AR.156/1, 2, 3; OB.5/1, 9/1; RS.384/1, 394/1, 2, 3, 4, 398/1, 412/1, 428/1; CL.5.5i/1 (cf.); FZ.1/1, 
10/1, 5.5i/1, 2, 3; TU2.5.5i/1, 2, 3 (cf.), 4, 5; TU3.5.5i/1, 4, 5 (cf.), 9, 10; TU4.5.5i/1, 2, 3, 4, 5, 6, 7, 8, 9, 10, 11; TU.20.2, 6, 10; RE.5.5i/3, 4; RB.5.5i/2 (in Goy, 1974, Pl. 83, fig.1, as Pseudolillia sp. A), 3 (in Goy, 1974, Pl. 83, fig. 2), 4 (cf.), 5 (in Comas-Rengifo, 1974, Pl. 10, figs 2 and 4, respectively); RB.C20/2 (cf.), 3 (cf.), 4 (cf.), 6 (cf.), 7; HU.5.5i/5, 6, 7 (cf.), 8 (cf.), 9, 10, 11 (cf.), 12, 13, 14 (cf.), 16, 17, 18, 19, 20; BS.80/1 (in Goy, 1974, Pl. 83, fig. 3 ), 2 (cf.), 3 (cf.), 4 (cf.), 5 (cf.); VC.5.5i/1, 2 (cf.), 3 (cf.), 4, 5; VC.5.5i(+1,2 $\mathrm{m}$ base)/ 6, 7, 8. Also there is one specimen from Obón (FSL.169015 Coll. Mouterde, in Elmi \& Rulleau, 1990, Pl. 5, figs. 3-4, Text-fig. 4).

All dimensions are indicated in Table 3.

Table 3. P. emiliana.

\begin{tabular}{|c|c|c|c|c|c|c|c|}
\hline ACRONYM & SPECIES & D & $\mathbf{O}$ & $\mathrm{O} / \mathrm{D}$ & H & $\mathbf{E}$ & E/H \\
\hline CM.13/1 & P. emiliana & 62.68 & 20.29 & 0.32 & 21.63 & 13.38 & 0.62 \\
\hline 4AR.156/1 & P. emiliana & - & - & - & 39.61 & 23.89 & 0.60 \\
\hline RS.394/1 & P. emiliana & - & - & - & 49.66 & 26.47 & 0.53 \\
\hline RS.394/2 & P. emiliana & 51.92 & 19.48 & 0.38 & 21.90 & 13.23 & 0.60 \\
\hline RS.394/3 & P. emiliana & - & - & - & 26.34 & 15.65 & 0.59 \\
\hline RS.394/4 & P. emiliana & - & - & - & 34.92 & 18.72 & 0.54 \\
\hline CL.5.5i/1 & P. cf. emiliana & - & - & - & 29.12 & 16.49 & 0.57 \\
\hline FZ.5.5i/1 & P. emiliana & 97.89 & 33.13 & 0.38 & 36.62 & 25.08 & 0.68 \\
\hline FZ.5.5i/2 & P. emiliana & 166.29 & 50.12 & 0.30 & 65.02 & 31.64 & 0.49 \\
\hline FZ.5.5i/3 & P. emiliana & - & - & - & 47.80 & 25.35 & 0.59 \\
\hline TU2.5.5i/1 & P. emiliana & - & - & - & 49.64 & 27.83 & 0.56 \\
\hline TU2.5.5i/2 & P. emiliana & - & - & - & 50.90 & 28.30 & 0.56 \\
\hline TU2.5.5i/3 & P. cf. emiliana & - & - & - & 21.39 & 13.02 & 0.61 \\
\hline TU2.5.5i/4 & P. emiliana & - & - & - & 20.80 & 13.83 & 0.66 \\
\hline TU2.5.5i/5 & P. emiliana & - & - & - & 30.76 & 18.80 & 0.60 \\
\hline TU3.5.5i/1 & P. emiliana & - & - & - & 39.42 & 18.80 & 0.48 \\
\hline TU3.5.5i/4 & P. emiliana & - & - & - & 44.40 & 24.30 & 0.55 \\
\hline TU3.5.5i/5 & P. cf. emiliana & - & - & - & 38.81 & 22.87 & 0.59 \\
\hline TU3.5.5i/9 & P. emiliana & - & - & - & 40.75 & 22.76 & 0.56 \\
\hline TU3.5.5i/10 & P. emiliana & - & - & - & 40.69 & 23.37 & 0.57 \\
\hline TU4.5.5i/1 & P. emiliana & - & - & - & 3.57 & 8.24 & 0.61 \\
\hline TU4.5.5i/2 & P. emiliana & - & - & - & 10.97 & 6.11 & 0.56 \\
\hline TU4.5.5i/3 & P. emiliana & - & - & - & 15.17 & 9.19 & 0.61 \\
\hline TU4.5.5i/4 & P. emiliana & - & - & - & 45.63 & 26.20 & 0.57 \\
\hline TU4.5.5i/5 & P. emiliana & - & - & - & 36.20 & 20.26 & 0.56 \\
\hline TU4.5.5i/6 & P. emiliana & - & - & - & 26.50 & 15.84 & 0.60 \\
\hline TU4.5.5i/7 & P. cf. emiliana & - & - & - & 17.40 & 10.53 & 0.61 \\
\hline TU4.5.5i/8 & P. emiliana & - & - & - & 36.45 & 20.25 & 0.56 \\
\hline TU4.5.5i/9 & P. emiliana & - & - & - & 44.50 & 24.10 & 0.55 \\
\hline RE. $5.5 \mathrm{i} / 3$ & P. emiliana & - & - & - & 38.83 & 22.14 & 0.57 \\
\hline RE. $5.5 \mathrm{i} / 4$ & P. emiliana & - & - & - & 18.26 & 10.96 & 0.60 \\
\hline RB.C20/3 & P. cf. emiliana & - & - & - & 12.49 & 8.29 & 0.66 \\
\hline
\end{tabular}

Description. Shells presenting a moderately involute coiling. The whorl section is relatively narrow and generally elliptical, presenting maximum thickness between the middle and the lower third of the whorl. The whorl section of the inner whorls can be compressed, presenting a subquadrate appearance. It exhibits a keel that is flanked by two more prominent grooves on the inner whorls, which become smoother and form flat areas on the outer whorls. The umbilicus is small and deep, with a high umbilical wall which is generally vertical or slightly oblique.

The ornamentation comprises thin straight or slightly sinuous ribs, on the sides, which curve sharply towards the body chamber in the ventral zone. They are rectiradiate

\begin{tabular}{|c|c|c|c|c|c|c|c|}
\hline ACRONYM & SPECIES & D & $\mathbf{O}$ & O/D & $\mathbf{H}$ & $\mathbf{E}$ & $\mathbf{E} / \mathbf{H}$ \\
\hline RB.C20/6 & P. cf. emiliana & - & - & - & 35.62 & 18.48 & 0.52 \\
\hline RB. $5.5 \mathrm{i} / 4$ & P. cf. emiliana & - & - & - & 49.03 & 28.43 & 0.58 \\
\hline HU.5.5i/5 & P. emiliana & - & - & - & 27.90 & 18.35 & 0.66 \\
\hline HU.5.5i/6 & P. emiliana & - & - & - & 40.49 & 24.11 & 0.60 \\
\hline HU.5.5i/9 & P. emiliana & 132.20 & 40.60 & 0.30 & 55.30 & 30.60 & 0.55 \\
\hline HU.5.5i/10 & P. emiliana & - & - & - & 72.73 & 33.79 & 0.46 \\
\hline HU.5.5i/11 & P. cf. emiliana & - & - & - & 61.53 & 30.48 & 0.50 \\
\hline HU.5.5i/12 & P. emiliana & - & - & - & 49.81 & 25.43 & 0.51 \\
\hline HU.5.5i/13 & P. emiliana & 69.96 & 19.50 & 0.28 & 30.68 & 18.80 & 0.61 \\
\hline HU.5.5i/16 & P. emiliana & - & - & - & 36.91 & 19.60 & 0.53 \\
\hline HU.5.5i/17 & P. emiliana & - & - & - & 25.08 & 14.71 & 0.59 \\
\hline HU.5.5i/18 & P. emiliana & - & - & - & 29.06 & 17.58 & 0.60 \\
\hline HU.5.5i/19 & P. emiliana & - & - & - & 29.21 & 19.55 & 0.67 \\
\hline HU.5.5i/20 & P. emiliana & - & - & - & 62.10 & 31.64 & 0.51 \\
\hline BS. $80 / 4$ & P. cf. emiliana & - & - & - & 13.46 & 9.91 & 0.74 \\
\hline BS. $80 / 5$ & P. cf. emiliana & - & - & - & 32.75 & 18.41 & 0.56 \\
\hline VC. $5.5 \mathrm{i} / 1$ & P. emiliana & 45.40 & 12.30 & 0.27 & 18.56 & 14.80 & 0.79 \\
\hline VC. $5.5 \mathrm{i} / 2$ & P. cf. emiliana & - & - & - & 48.60 & 25.28 & 0.52 \\
\hline VC. $5.5 \mathrm{i} / 3$ & P. cf. emiliana & - & - & - & 13.01 & 8.06 & 0.62 \\
\hline VC. $5.5 \mathrm{i} / 4$ & P. emiliana & 105.00 & 34.40 & 0.33 & 39.20 & 23.80 & 0.60 \\
\hline VC. $5.5 \mathrm{i} / 5$ & P. emiliana & - & - & - & 27.11 & 13.50 & 0.50 \\
\hline VC.5.5i $(+1,2) / 6$ & P. emiliana & - & - & - & 48.90 & 26.76 & 0.55 \\
\hline VC.5.5i $(+1,2) / 7$ & P. emiliana & - & - & - & 60.10 & 32.25 & 0.54 \\
\hline VC. $5.5 \mathrm{i}(+1,2) / 8$ & P. emiliana & - & - & - & 56.92 & 31.20 & 0.55 \\
\hline
\end{tabular}


or slightly proverse and are never prolonged as far as the keel. Density is high in the inner whorls and is lost during ontogeny. It generally disappears completely for whorl heights of $60 \mathrm{~mm}$, although, given the noteworthy variability of the taxon, they might disappear earlier.

The suture line is relatively simple. Two elements stand out; the first of these, the lateral saddle, which is wide and bilobed; and the lateral lobe, which is deep and cropped. The second lateral saddle is narrower than the first one, as is the suspensive lobe.

Remarks. $P$. emiliana is the species most cited and figured of Pseudolillia, and it is also the taxon to which most of our specimens belong. They exhibit great variability, which makes it difficult to accurately describe them. The biconvex section of the whorl enables this species to be differentiated from $P$. murvillensis and $P$. hispanica, whose whorl sections are subtrapezoidal and subtriangular, respectively. It is also relatively simple to differentiate them from $P$. donovani and from Pseudolillia ? n. sp., due to their different coilings and to the bigger size of the umbilicus.

Variations can be observed within the taxon in relation to the ribbing. Thus, specimens TU2.5.5i/2, RE.5.5i/3 and HU.5.5i/20 and those figured by Goy (1974, Pl. 83, fig. 3) and by Elmi \& Rulleau (1990, Pl. 6, figs. 3-4) present thicker and more spaced ribs, which are slightly more proverse, a fact that makes them similar to $P$. murvillensis.

Geographic and stratigraphic distribution. The specimens studied are mostly from the Iberian Range (Muro de Aguas, Castrovido, Hontoria del Pinar, Ricla, Ariño, Obón, Rambla del Salto, Clares, Fuentelsaz, Turmiel, Renales, Ribarredonda, Huertahernando, Buenafuente del Sistal and Villar de Cobeta). Additionally, we examined some specimens from the Cantabrian Range, from Camino, San Andrés and Salinas de Pisuerga, and a specimen from Santa Mera (Asturias), cited as $P$. cf. emiliana (Rèynes) by Suárez Vega $(1974$, p. 74) and recorded slightly above Pseudogrammoceras subfallaciosum Buckman, which is deposited in the Jurassic Museum of Asturias (MUJA).

The stratigraphic position of $P$. emiliana corresponds to the top of the Dispansum Chronozone, Insigne Subchronozone in the NW-European Province (Goy, 1974; Guex, 1975; Goy et al., 1988; Elmi et al., 1989, 1997; Elmi \& Roulleau, 1990; Bécaud, 2006). Exceptionally, in the Rambla del Salto (Teruel) section, this species persists up to the base of the Gruneri Subchronozone (Comas-Rengifo et al., 1996). In the Mediterranean Province it has been cited in the Speciosum Chronozone (Gabilly et al., 1971; Géczy, 1985; Goy et al., 1988; Mouterde \& Elmi, 1991; Elmi et al., 1997, 2007; Kovács, 2013).
Pseudolillia donovani García-Gómez \& Rivas, 1980 (Fig. 4G, Figs 10.1-10.5, Fig. 11.2)

1962 Pseudolillia aff. murvillensis Maubeuge, Donovan, Text-figs. 2a-b.

1980 Pseudolillia donovani n. sp. García-Gómez \& Rivas, p. 197, Pl. 1, fig. 1; Pl. 2, figs. 1-2; Pl. 3, fig. 1.

1990 Pseudolillia donovani, Elmi \& Rulleau, p. 299, Pl. 7, figs.1-4.

Material. RS.379/1; RS.380/1; TU3.5.4s/7; TU3.5.4s/8; TU.19T; RB.19/1, 2, 3; RB.5.4s/1, 2; VC.5.4s/1; CU.11/1, 5 (cf.).

Sizes are shown in Table 4.

Table 4. P. donovani.

\begin{tabular}{lccccccc}
\hline ACRONYM & SPECIES & D & O & O/D & H & E & E/H \\
\hline RS.379/1 & P. donovani & 68.02 & 27.69 & 0.41 & 22.00 & 12.50 & 0.57 \\
RS.380/1 & P. donovani & 44.38 & 17.43 & 0.39 & 17.58 & 7.81 & 0.44 \\
TU3.5.4s/7 & P. donovani & - & - & - & 65.26 & 40.24 & 0.62 \\
TU3.5.4s/8 & P. donovani & - & - & - & 31.00 & 16.04 & 0.52 \\
RB.5.4s/1 & P. donovani & 73.7 & 26.40 & 0.35 & 30.58 & 18.9 & 0.61 \\
RB.5.4s/2 & P.donovani & 65.40 & 22.20 & 0.33 & 25.24 & 14.00 & 0.55 \\
RB.C19/1 & P. donovani & - & - & - & 14.01 & 8.47 & 0.60 \\
VC.5.4s/1 & P. donovani & - & - & - & 29.9 & 19.64 & 0.62 \\
CU.11/1 & P. donovani & 32.78 & 13.58 & 0.41 & 15.54 & 9.37 & 0.60 \\
CU.11/5 & P. cf. donovani & - & - & - & 11.72 & 2.75 & 0.23 \\
\hline
\end{tabular}

Description. Shells presenting an evolute coiling. The section is similar to that of $P$. emiliana, high and straight, but less elliptical. The maximum thickness of the section is situated in the lower third of the flank. Most of the specimens present a keel in the ventral zone flanked by two flat areas that could be grooves in an early stage. The umbilicus is relatively large in relation to that of other species of the genus, and could represent up to $41 \%$ of the shell diameter. The umbilical wall is low and occasionally almost vertical.

The ornamentation comprises thin ribs that are straight or sinuous and slightly proverse and which reach the grooves of the ventral zone. Density is high in the internal whorls, but it gradually diminishes and disappears completely for whorl heights of $30 \mathrm{~mm}$. The suture line can be observed in specimens TU3. 5.4s/8 (Fig. 10.3) and TU3.5.4s/7 (Fig. 11.2), although their state of conservation does not always allow an accurate description of all the elements. The lateral saddle can be seen to divide into two lobes and, as pointed out by García-Gómez \& Rivas (1980), the external one is bigger than the internal one, the lateral lobe is deep, but narrower than in P. emiliana, and the second lateral saddle is relatively narrow. 


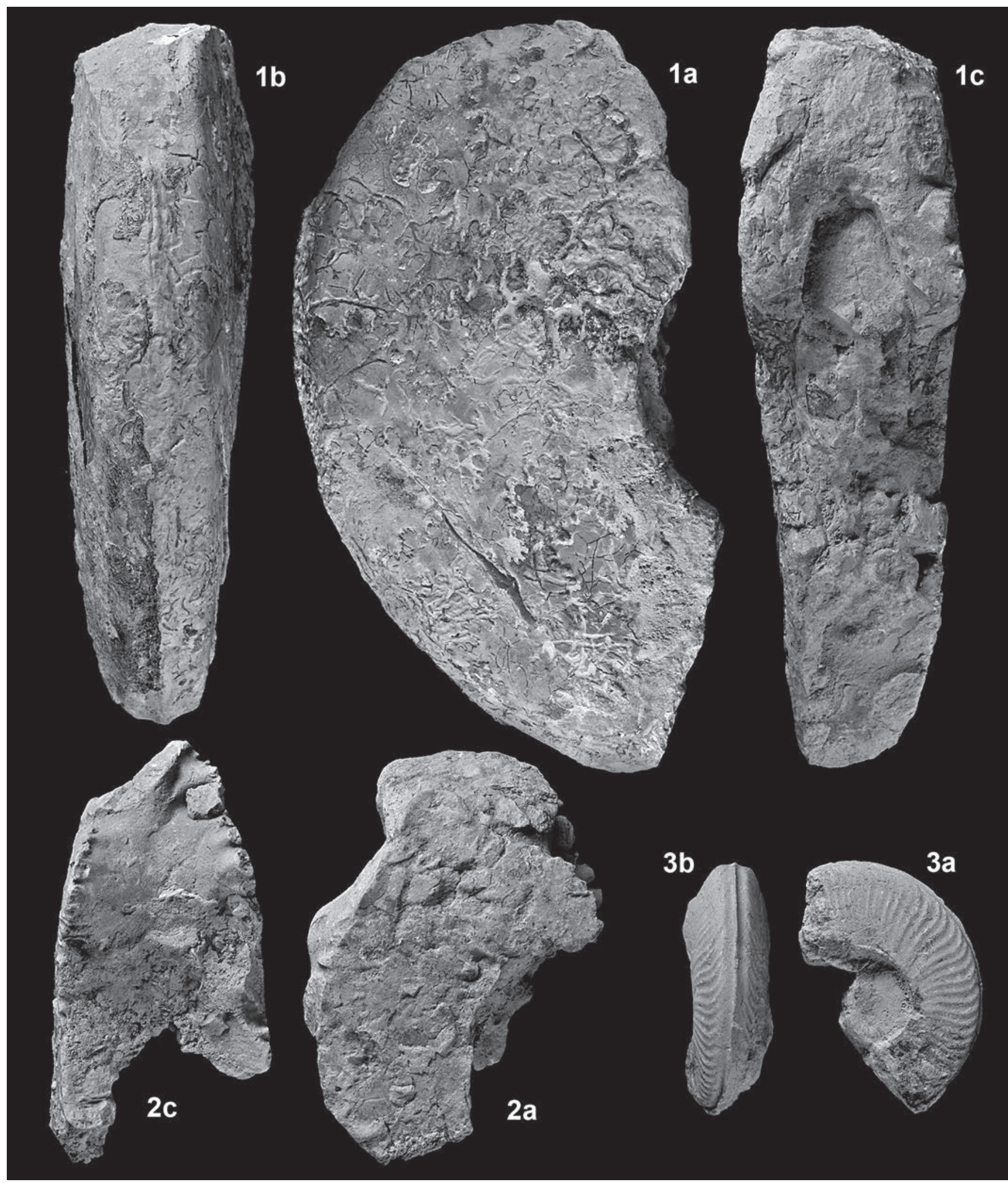

Figure 5. (1, 3) Pseudolillia murvillensis. 1) Incomplete phragmocone. BB.5.5i/1. 3) Incomplete phragmocone, inner whorls. RS.386/1.

(2) Pseudolillia cf. murvillensis. Incomplete phragmocone. RB.C20/1. Dispansum Chronozone (Insigne Subchronozone). All figures natural size. 


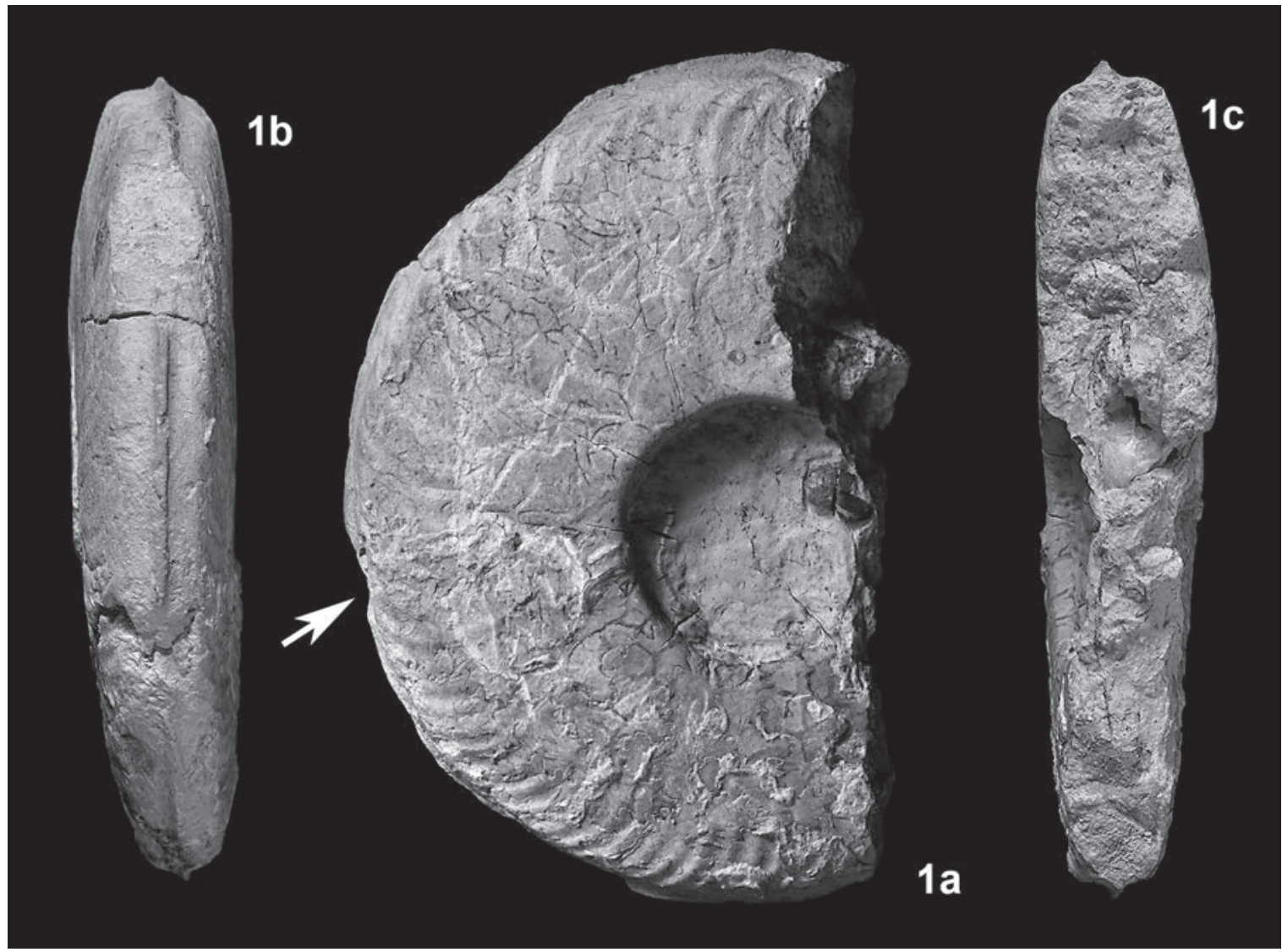

Figure 6. Pseudolillia hispanica. Incomplete colonized phragmocone. RB.5.5i/7 (figured in Comas-Rengifo, 1974, Pl. 20. fig. 4). The arrow marks the end of the phragmocone.

Remarks. The character that most easily helps to differentiate the taxon from P. emiliana is the larger $\mathrm{O} / \mathrm{D}$ ratio, as well as notable differences in ontogeny, as pointed out by García-Gómez \& Rivas (1980). There is a clear loss of ornamentation for whorl heights of over 30 $\mathrm{mm}$. Specimen TU3.5.5i/7 (Fig. 11.2) is one of the few within this taxon, and even among all those of the genus, conserving a part of the body chamber, which displays a greater degree of deformation and fracture than the phragmocone.

$P$. donovani presents notable analogies with the specimen described by Sassaroli \& Venturi (2005) as Pseudolillia apenninica n. sp. from Cingoli (Central Appenines), as the section, the ribbing and the suture line are similar, and the umbilicus is only somewhat bigger in the Italian specimen.

Geographic and stratigraphic distribution. This species was identified in several localities of the Iberian Range (Rambla del Salto, Turmiel, Ribarredonda and Villar de Cobeta) and in Puig de Cutri in Majorca. The specimens of García-Gómez \& Rivas (1980) are from el Zegrí (Granada). It was also cited in France, in the quarries of Lafarge, by Elmi \& Rulleau (1990).
The specimens from the Iberian Range are situated in the upper part of the Thouarsense Chronozone (Fallaciosum Subchronozone), as is the specimen of Elmi \& Rulleau (1990). The specimens of García-Gómez \& Rivas (1980) are from the "ammonitico rosso" facies from the upper part of the Fallaciosum Zone (in Goy et al., 1988), which likely corresponds to the transition between the Bonarelli and Speciosum chronozones of the standard scale of the Mediterranean Province (Elmi et al., 1997; Page, 2003). Sassaroli \& Venturi (2005) situate P. apenninica in the Bonarelli Zone of the Mediterranean province which, according to Elmi et al. (1997), is equivalent to the Thouarsense Zone of the NE-European Province.

\section{Pseudolillia ? n. sp. (in García-Gómez \& Rivas, 1980)} (Fig. 10.6)

1980 Pseudolillia ? n. sp. García-Gomez \& Rivas, p. 199, Pl. 1, fig. 2.

Material. CU.11/4, 6; CU.11/6-- $D=51,20 ; \mathrm{O}=21,57$; $\mathrm{O} / \mathrm{D}=0,42 ; \mathrm{H}=19,44 ; \mathrm{E}=15,50 ; \mathrm{E} / \mathrm{H}=0,79$.

Description. Evolute, with a high, relatively narrow section with convex sides. The maximum width is in the 


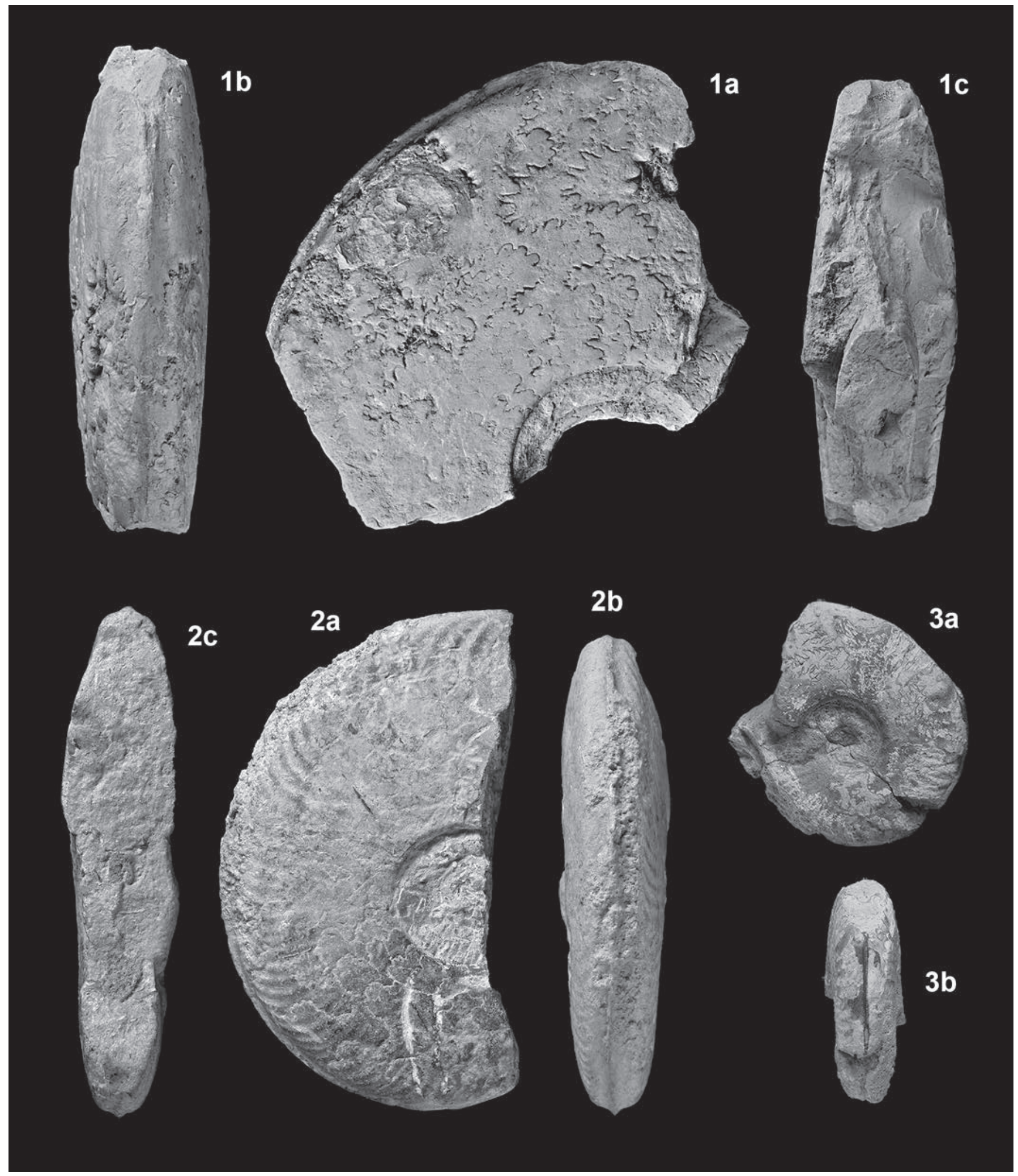

Figure 7. (1, 2) Pseudolillia hispanica. 1) Incomplete colonized phragmocone. RB.5.5i/1. 2) Incomplete phragmocone. AN.567J/1. 3) Pseudolillia emiliana. Incomplete phragmocone. VC.5.5i/1. Dispansum Chronozone (Insigne Subchronozone). All figures natural size. 


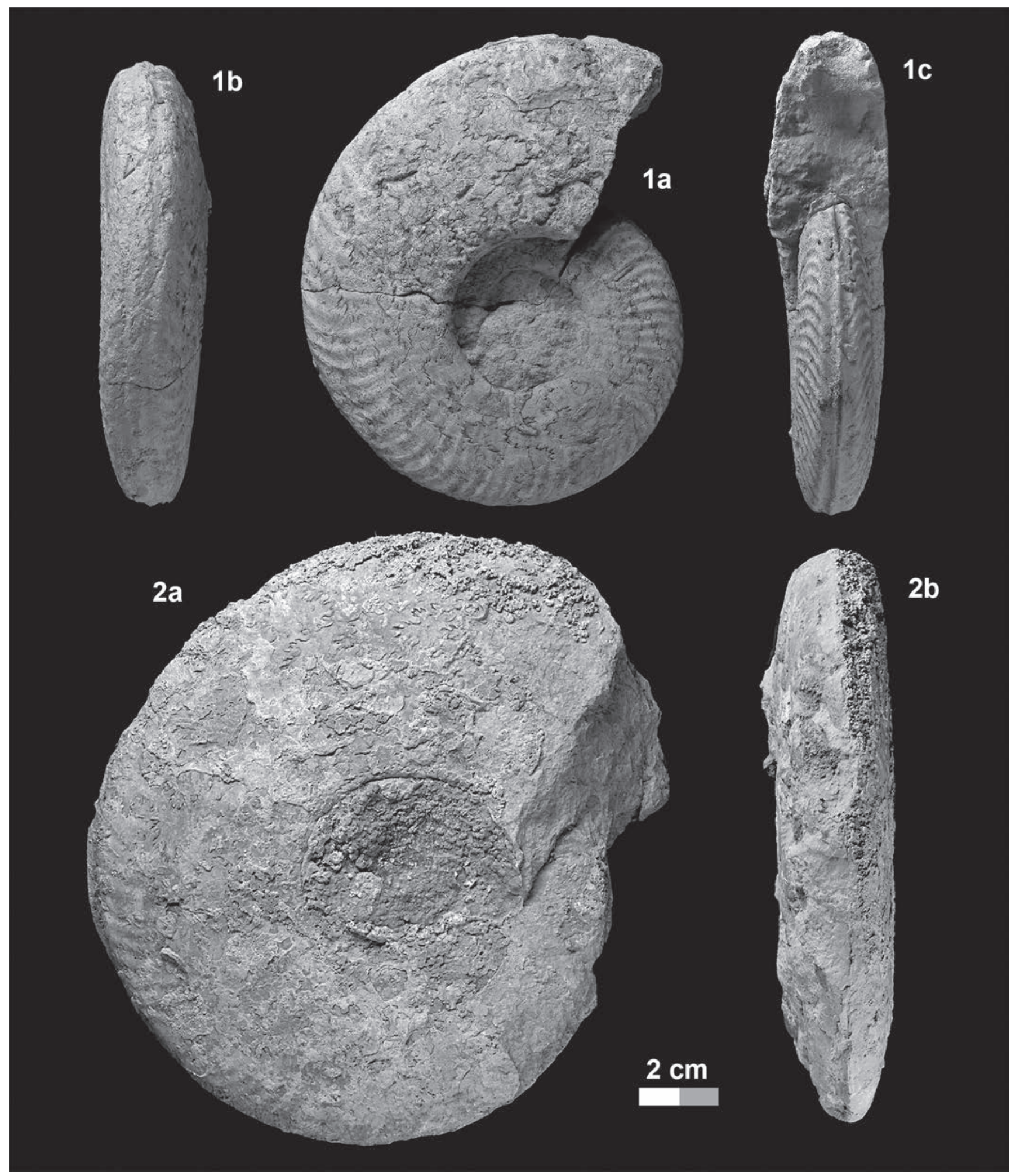

Figure 8. Pseudolillia emiliana. 1) Incomplete phragmocone with one of the slightly eroded flanks. FZ.5.5i/1. 2) Incomplete phragmocone colonized by serpulids and with carbonate crusting. FZ.5.5i/2). Dispansum Chronozone (Insigne Subchronozone). 


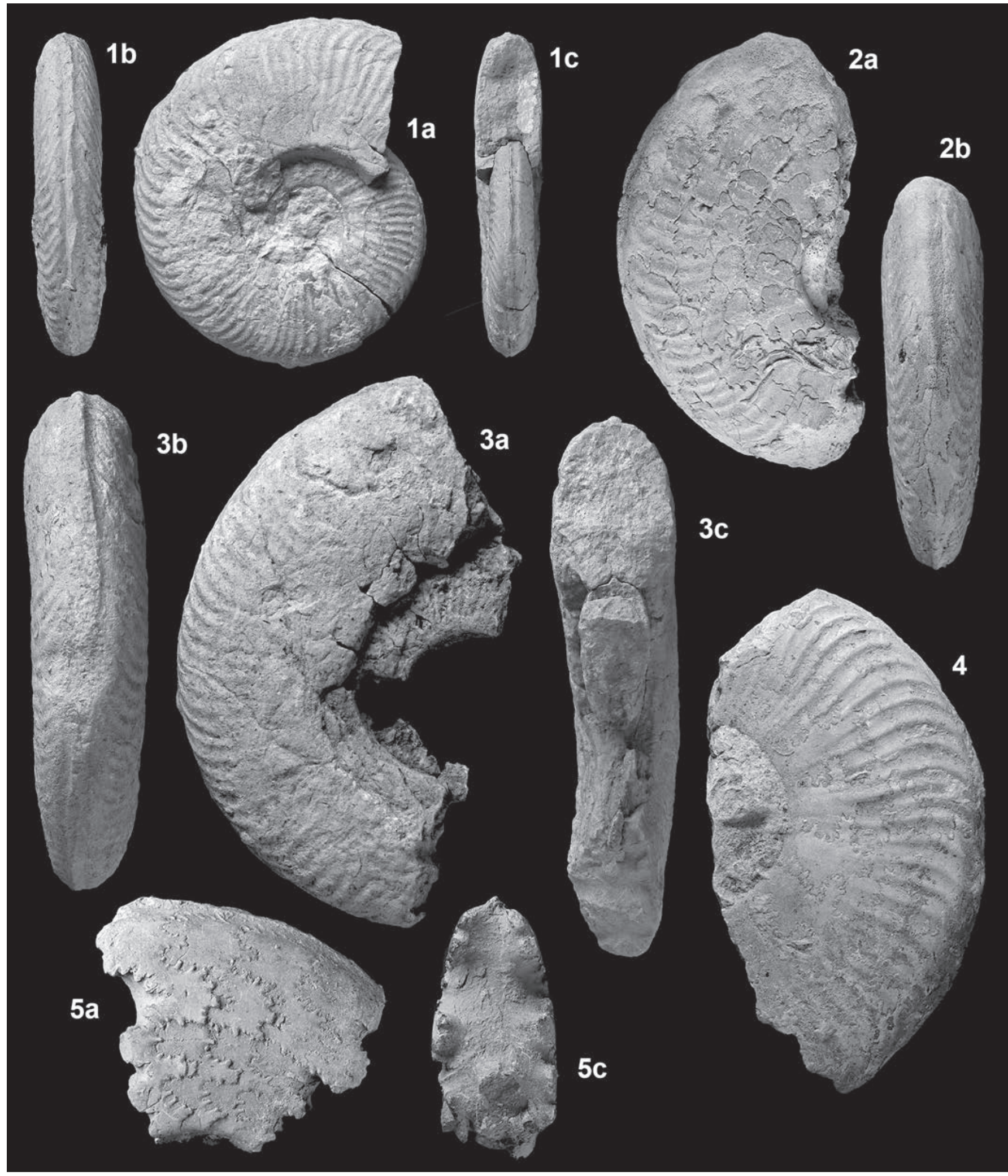

Figure 9. Pseudolillia emiliana. 1) Incomplete phragmocone. CM.13/1. 2) Incomplete phragmocone colonized by serpulids in both flanks. RS.394/4. 3) Incomplete phragmocone. The specimen is slightly deformed and eroded. VC.5.5i/4. 4) Incomplete phragmocone. 4AR.156/1. 5) Incomplete phragmocone. TU3.5.5i/4. Dispansum Chronozone (Insigne Subchronozone). All figures natural size. 
lower third of the whorl height. The ventral region is seen to be somewhat rounded, which might be due to erosion, as the specimens described are from a reelaborated level. The umbilicus is large; the biggest of all the taxa described and the umbilical wall is high, with an inclination close to vertical. The poor state of preservation does not enable sound analysis of the ornamentation, which appears to comprise thin straight ribs, or description of the suture line.

Remarks. The intense wear and the presence of manganese crusting on the fossil (Fig. 10.6) prevented a complete description of its morphological features; this might also have modified the appearance of the ventral zone.

The specimens are assigned to Pseudolillia ? n. sp., because their general characteristics fit well with the description given by García-Gómez \& Rivas (1980), with the exception that in the specimen from Majorca the ventral region cannot be clearly observed and it is therefore unfeasible to confirm the presence of a keel flanked by two wide, shallow grooves.

The size of the umbilicus, over $42 \%$ of the diameter, indicates slower growth than in the other species (GarcíaGómez \& Rivas, 1980), and this character separates this taxon from P. emiliana.

Geographic and stratigraphic distribution. GarcíaGómez \& Rivas (1980) cite this species in the Betic Range, from Cerro Méndez (Granada), and specimen CU.11/6 is from the Sierra del Llevant Mountains (Majorca).

The stratigraphic position of this taxon is unclear, since García-Gómez \& Rivas (1980) only indicate that it was found together with Pseudogrammoceras and the specimen from Majorca comes from a level of the Puig de Cutri section with reelaborated ammonites, showing a taxorecord representing all the chronozones of the upper Toarcian and of the basal Aalenian.

Pseudolillia ? sp.

(Fig. 4H, Fig. 10.7)

Material. CU.11/2, 3.

Description. Shell with moderately involute coiling. The section is high and elliptical (Fig. 4.H). The ventral region is rounded. It presents a high and vertical umbilical wall. Due to its state of conservation, no ornamentation can be observed; neither can the suture line be described.

Remarks. Due to its characteristics it is interpreted as a possible specimen of the genus Pseudolillia, although it cannot be included in any of the above described taxa. The specimens are reelaborated and come from a level presenting manganese crusting. It is possible that the rounded appearance of the ventral region is due to wear resulting from abrasion of the internal mould.
Geographic and stratigraphic distribution. They were collected in the Puig de Cutri section (Isle of Majorca). The stratigraphic position is not precise because it comes from a layer containing reelaborated ammonites from much of the upper Toarcian and the basal Aalenian.

\section{Pseudolillia spp.}

Material. SM.105/1, 111/1, 2, Pseudolillia sp. (in Goy et al., 2010); SA.98/1, Pseudolillia sp. (in Goy et al., 1994); CV.3.8/1, Pseudolillia sp. (in Ureta, 1977); TU1.5.4s/1; TU3.5.5i/2; RB.C20/5, 8; HU.5.4s/1; HU.5.5i/21, 22; BS.79?/1, 80?/3, 4, Pseudolillia sp.

Herein are included some specimens that could not be attributed to a specific species. TU.5.4s/1, HU.5.4s/1 and BS.79?/1 are from the terminal part of Turmiel Formation (Rhythmic alternation of marls and limestones $\mathrm{Mb}$ ) which, practically throughout the Iberian Range, has been dated as being from the Thouarsense Chronozone (Fallaciosum Subchronozone). TU3.5.5i/2, HU.5.5i/21, 22 and BS.80?/3, 4 , which come from the lower part of Turmiel Formation (Marls and marly limestones $\mathrm{Mb}$ ), have been dated as being from the Dispansum Chronozone (Insigne Subchronozone) (Goy et al., 1976; Gómez et al., 2003). Furthermore, specimens RB.C20/5, 8, CV.3.8/1, SA.98/1, SM.105/1 and SM.111/1, 2 were associated with ammonites typical of the Dispansum Chronozone (Insigne Subchronozone) in detailed sections of Ribarredonda, Castrovido, San Andrés and Santa Mera (Comas-Rengifo \& Goy, 1975; Ureta, 1977; Goy et al. 1994, 2010).

\section{DISCUSSION}

With the exception of Maubeuge (1949) and Arkell et al. (1957), who included the genus Pseudolillia in Phymatoceratinae, all other authors who studied this genus situated it in the Subfamily Grammoceratinae. However, the origin of the latter subfamily is controversial and several hypotheses have been proposed: a) it descends from Mediterranean Mercaticeras (Donovan, 1962); b) the subfamily is of NW-European origin following a migration; or 3) it presents a double origin from Mercaticeratinae and Phymatoceratinae such as Denckmannia chelussi Parisch \& Viale (Gabillly, 1976, p. 75). Maubeuge (1949) stated that the morphology of Pseudolillia is difficult to compare with any known taxon, although he highlighted its proximity to the genus Lillia and the genus Crassiceras. Arkell et al. (1957) did not recognise the genus and included it as a synonym of Brodieia. The proximity with the previously cited genera appears to situate Pseudolillia in the Subfamily Phymatoceratinae. These observations are due to the alleged joining of the ribs in the lower part of 


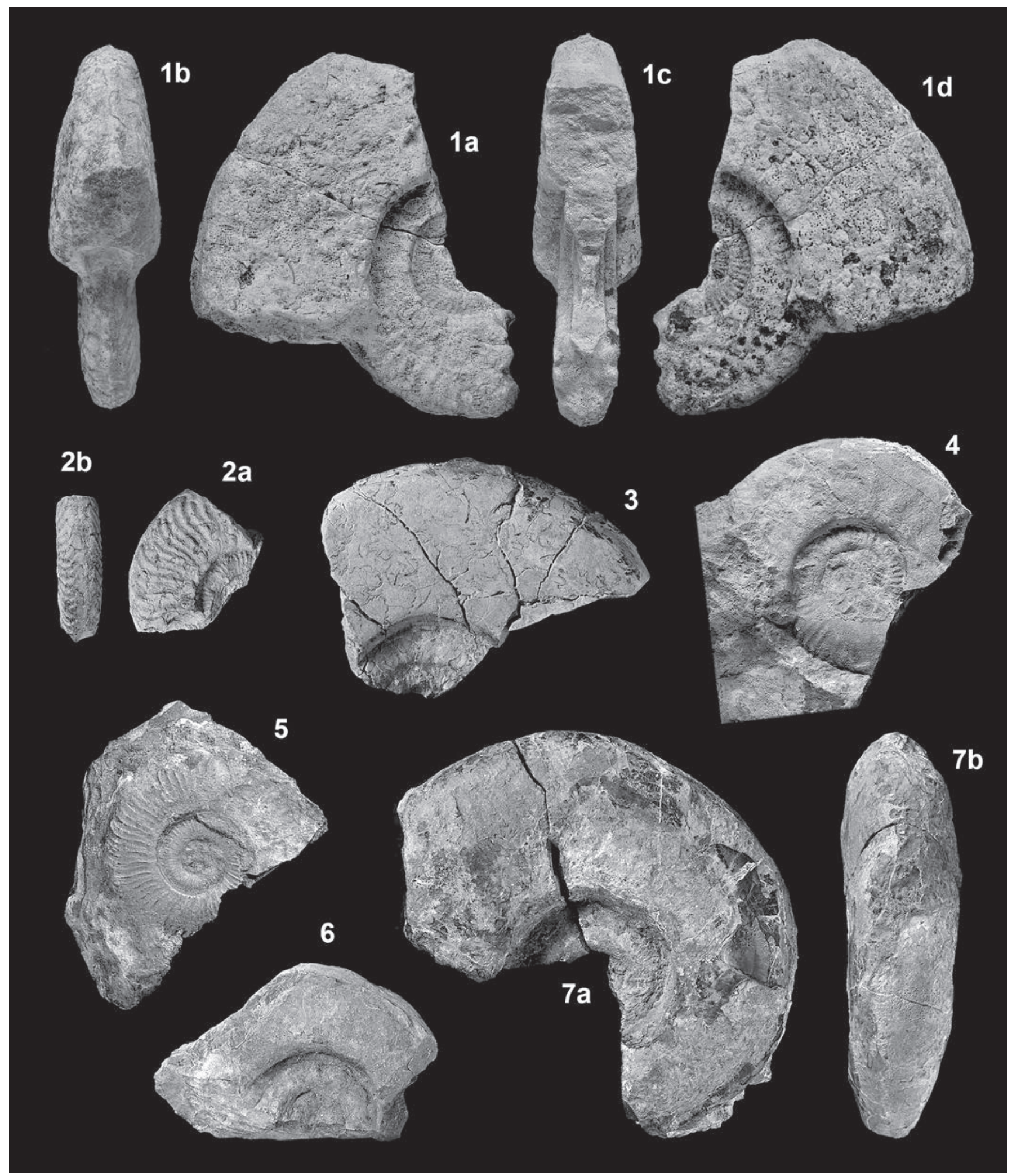

Figure 10. (1-5) Pseudolillia donovani. 1) RB.5.4s/1. 2) Incomplete phragmocone. RB.C19/1. 3) Incomplete phragmocone. TU3.5.4s/8. 4) Incomplete phragmocone. RS.380/1. 5) Incomplete phragmocone. CU.11/1. (6) Pseudolillia ? n. sp. García-Gómez \& Rivas. Incomplete phragmocone. CU.11/6. (7) Pseudolillia ? sp. Incomplete phragmocone with manganese crust. CU.11/3. Thouarsense Chronozone (Fallaciosum Subchronozone). All figures natural size. 


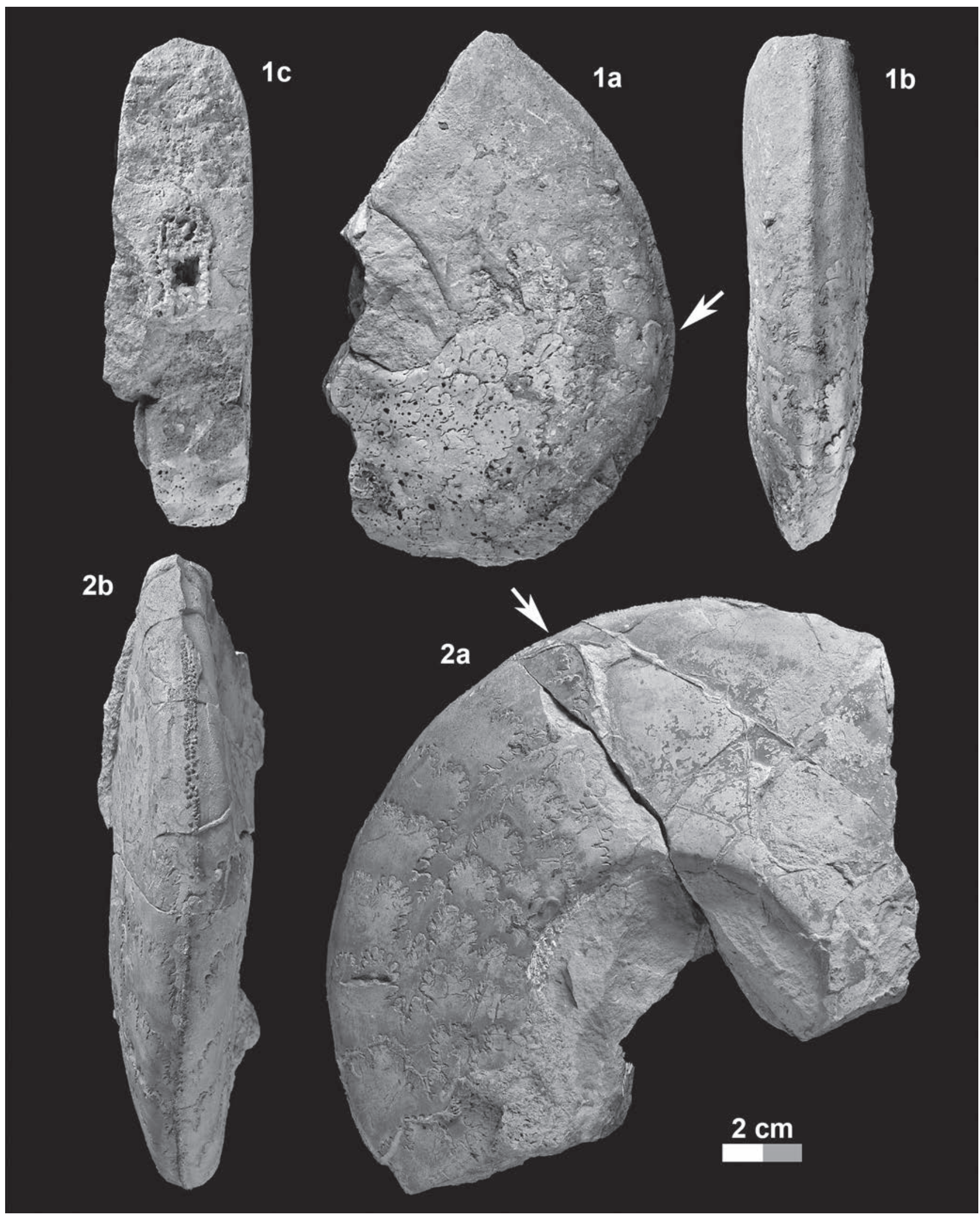

Figure 11. 1) Pseudolillia murvillensis. Fragment of shell that retains a part of the body chamber. The arrow marks the end of the phragmocone and it is possible to observe the crystallization of calcite in the inner whorls. HU.5.5i/3. Dispansum Chronozone (Insigne Subchronozone). 2) Pseudolillia donovani. Fragment of shell that retains a part of the body chamber, which is crushed and fractured. TU3.5.4s/7. Thouarsense Chronozone (Fallaciosum Subchronozone). 
the flank (cf. Maubeuge, 1949). Donovan (1962) assigned the genus to Grammoceratinae owing to the straight ribs in the internal whorls, a character this author includes in the description of the genus, and which can be observed in other genera of the subfamily such as Dumortieria.

Guex (1975) suggested an origin of the group in some last representatives of Grammoceras from the Thouarsense Zone (Fascigerum Subzone), giving the example of G. striatulum (Sowerby), which he situated as an intermediate step between Grammoceras and Pseudolillia, and Gabilly (1976) maintained Pseudolillia within the Grammoceratinae, but stated that the genus might equally derive from last representatives of the Phymatoceratinae. García-Gómez \& Rivas (1980) also rejected the idea that the ribs are joined at the lower part of the flank (at least in $P$. donovani) and they highlight the great similarities between Esericeras and Pseudolillia, which display only slight differences in the ribbing and the suture line (more simplified in Pseudolillia). In view of the previous studies Rulleau $(1989,1994)$ and Elmi \& Rulleau (1990) concluded that the origin of the genus should be sought in the last Grammoceras or in Esericeras. It has been speculated that Pseudolillia is related to Esericeras ? loeve (Gabilly), whose section is reminiscent of $P$. donovani. Nonetheless, E. ? loeve has a smaller umbilicus and displays no ornamentation, a fact that distinguishes it from $P$. donovani. Following the studies by Bécaud (2006), any possible relationship must be ruled out, because the species described in France, Osperlioceras (Pseudopolyplectus) loeve (Gabilly), corresponds to the lower part of the Variabilis Chronozone. In summary, $P$. donovani or related forms most likely derive from Esericeras close to E. fascigerum, which is the closest species in degree of involution, as well as in the appearance of the section and of the ribbing.

Furthermore, the palaeobiogeographic distribution of the genus Pseudolillia is relatively small. It ranges from the southern part of the NW-European province (France and E and $\mathrm{N}$ of Spain) to different outcrops of the Mediterranean or Sub-Mediterranean Provinces (Portugal, S of Spain, Majorca, Eastern Italy, Hungary, Bulgaria, Mid-Atlas and High Atlas). Its stratigraphic distribution ranges from the Thouarsense Chronozone (Fallaciosum Subchronozone) of the NW-European Province equivalent to the upper part of the Bonarelli Zone of the Mediterranean province to the Dispansum/Speciosum Chronozone (Insigne/Speciosum Subchronozone). The Figure 12 shows the detailed geographic distribution of the main species recognised in Spain. P. emiliana is the species exhibiting the broadest geographic distribution, occupying practically the whole known distribution range of the genus. P. murvillensis has a smaller range, limited to the $\mathrm{N}$ of France, the region of Lyon, Spain's eastern Pyrenees and the central sector of the Castilian Branch of the Iberian Range. P. donovani is distributed throughout a more southern area from the central sector of the Castilian Branch to the Betic Range in the Granada area and the east of Majorca, and perhaps occasionally in the Central Appenines (Italy). Lastly, P. hispanica has only been recorded in the Betic Range and in the central sector of the Castilian Branch of the Iberian Range. As for the stratigraphic position, $P$. donovani is the oldest species, which is distributed throughout a part of the Mediterranean Province during the Thouarsense Chronozone (Fallaciosum Subchronozone), whereas $P$. murvillensis (Dispansum Chronozone, Insigne Subchronozone) is a species typical of NW Europe. The record of $P$. emiliana (Dispansum Chronozone, Insigne Subchronozone) extends throughout the two aforementioned provinces and P. hispanica is likely an endemic species with a very small geographic range and a stratigraphic position that is limited to the base of the Dispansum Chronozone.

\section{CONCLUSIONS}

The study of the specimens attributed to Pseudolillia in sections of the $\mathrm{E}$ and $\mathrm{N}$ of Spain has enabled the following species to be characterised: in the Cantabrian Range $P$. emiliana, in the Iberian Range P. murvillensis, P. hispanica, $P$. emiliana and $P$. donovani, and on the Isle of Majorca, $P$. donovani, Pseudolillia n. sp. (in García-Gómez \& Rivas, 1980), P. cf. emiliana and Pseudolillia ? sp.

The stratigraphic distribution of the species identified appears to indicate that Pseudolillia is a genus of the upper Toarcian and that the species characterised in the NE of Spain present the following position: $P$. donovani is a species from the Thouarsense Chronozone (Fallaciosum Subchronozone); P. murvillensis and $P$. hispanica are species from the Dispansum Chronozone (Insigne Subchronozone) and P. emiliana is a relatively frequent species in the Dispansum Chronozone (Insigne Subchronozone), which could have survived up to the Gruneri Subchronozone, but which did not coexist with the oldest species of Dumortieria (D. pseudodumortieri Rulleau). The position of Pseudolillia ? n. sp. (in García-Gómez \& Rivas, 1980), which these authors found with Pseudogrammoceras in Cerro Méndez (Granada), is also imprecise on the Isle of Majorca, as it comes from a decimetric remobilisation level with reelaborated ammonites corresponding to several zones of the upper Toarcian and from the basal Aalenian. The same inaccuracy occurs with the specimen described as Pseudolillia? sp.

Our study does not accurately establish the origin of the genus Pseudolillia. The succession of the ammonites in the study area is compatible with a derivation from last representatives of Grammoceras or Esericeras. 
Their morphological characters (coils, whorl section, ornamentation and suture line) most likely indicate that they derive from Esericeras, close to the species $E$. fascigerum.

The geographic distribution of the genus Pseudolillia is limited to Europe and N Africa. P. emiliana is the species exhibiting the broadest distribution, because it is known in practically all the regions where the genus has been cited; the species $P$. murvillensis presents a relatively small distribution, which has been recorded in areas of the NW-European province, between Lorraine (France) and the central sector of the Iberian Range and $P$. donovani is a species typical of the Mediterranean Province which has also been recorded in the central sector of the Iberian Range, it is unsure whether it lived on the Iberian platforms.

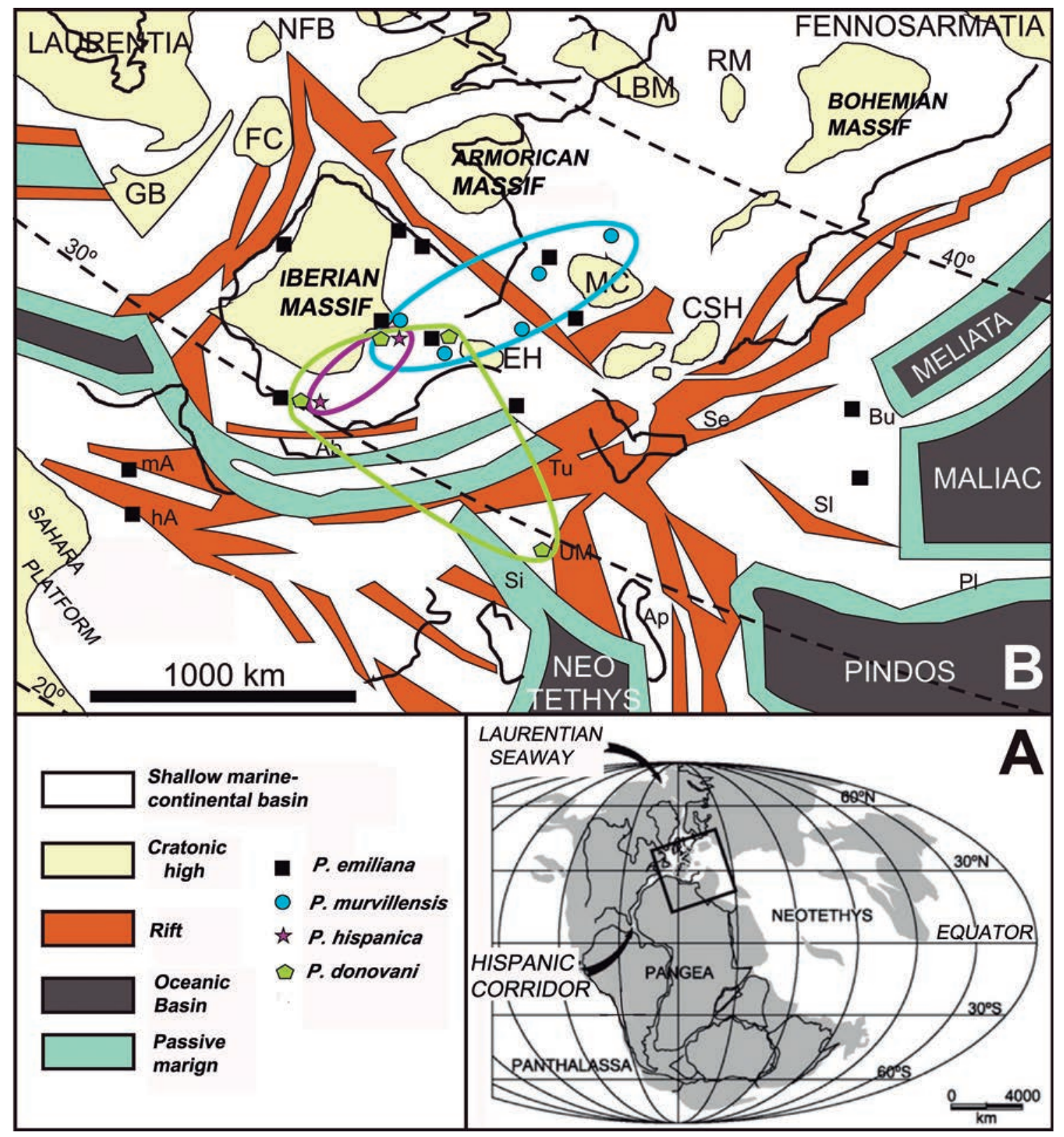

Figura 12. a) Palaeographical map for the Toarcian (modified after Golonka, 2007), showing the position of the studied area. b) Palaeographical map (modified after García Joral et al., 2011) and palaeobiogeographic distribution of species Pseudolillia. Ab: Alboran; Ap: Apulia; Bu: Bucovinian; CSH: Corsica-Sardinia High; EH: Ebro High; FC: Flemish Cap; GB: Grand Bank; hA: High Atlas; LBM: London-Braband Massif; MC: Massif Central High; mA: Middle Atlas; NFB: East Newfoundland Basin; Sl: Slavonia; Pl: Pelagonian; RM: Rhenish Massif; Si: Sicanian; Tu: Tuscan; UM: Umbria-Marche. 


\section{ACKNOWLEDGEMENTS}

Our more sincere thanks to Prof. Dr. Pascual Rivas, of the University of Granada, for all the many conversations discussing the Paleontology of the Toarcian ammonoids, particularly concerning the difficulties of correlating the Betic Cordillera and NE Spain with taxa belonging to different palaeobiogeographic provinces. We are also grateful to both Drs. Isabel Rábano and Ana Rodrigo of the Geominero Museum and to José Carlos García Ramos and Laura Piñuela of the Museum of Jurassic of Asturias, for making available the specimens deposited in both institutions for the revision undertaken in this paper. We thank Dr. G. Martínez, one anonymous reviewer and the editors for their comments and suggestions that improved the manuscript. We are also grateful to Carlos Alonso Recio (Palaeontology Department, Universidad Complutense) for the digital processing of photographs, and to Cormac de Brun for reviewing the English version. This research work was financed by project CGL2015-66604-R of the Spanish Ministerio de Economía y Competitividad, and by projects GR3/14/910431 of the Universidad Complutense de Madrid.

\section{REFERENCES}

Álvaro, M., Barnolas, A., Olmo, P. del, Ramírez del Pozo, J. \& Simó, A. 1984. Estratigrafía del Jurásico. In: Sedimentología del Jurásico de Mallorca (eds Álvaro, M., Barnolas, A., Olmo, P. del, Ramírez del Pozo, J. \& Simó, A.). GEM-IGME-CGS, 43-71.

Álvaro, M., Barnolas, A., Cabra, P., Comas-Rengifo, M.J., Fernández-López, S.R., Goy, A., Olmo, P. del, Ramírez del Pozo, J., Simó, A. \& Ureta, S. 1989. El Jurásico de Mallorca. Cuadernos de Geología Ibérica, 13, 67-120.

Arkell, W.J., Furnish, W.M., Kummel, B., Miller, A.K., Moore, R.C., Schindewolf, O.H., Sylvester-Bradley, P.C. \& Wright, C.W. 1957. Cephalopoda, Ammonoidea. In: Treatise on Invertebrate Paleontology, Part L, Molluca 4, (ed. Moore, R.C.). University of Kansas Press, 490 pp.

Bécaud, M. 2006. Los Harpoceratinae, Hildoceratinae y Paroniceratinae du Toarcien de la Vendée et Deux-Sèvres (France). Documents des Laboratoires de géologie Lyon, 162, $245 \mathrm{pp}$.

Bernad, J. 1992. El Toarciense en la región de CillamayorSalinas del Pisuerga (Cuenca Vasco-cantábrica, Paleontología (Ammonoideos) y Bioestratigrafía. M.Sc. Thesis, Universidad Complutense de Madrid (unplished)

Bernad, J. 1993. Ammonitina del Toarciense en Salinas de Pisuerga (Palencia, España). Coloquios de Paleontología, 45, 91-136.

Buckman, S.S. 1905. A monograph of the Inferior Oolite ammonites of the British Islands, Part 13. Monograph of the Palaeontographical Society London, Supplement, 169-208.
Caracuel, J.E., Fernández-López, S.R., Tent-Manclús, J.E. \& Yébenes, A. 2004. Itinerario paleontológico por el Cerro de la Cruz (Sierra de Reclot). In: Geología de Alicante (eds Alfaro, P., Andreu, J.M., Estévez, A., Tent-Manclús, J.E. \& Yébenes, A.). Universidad de Alicante, 245-260.

Comas-Rengifo, M.J. 1974. Estudio paleontológico y bioestratigráfico del Jurásico de Ribarredonda. M.Sc. Thesis, Universidad Complutense de Madrid (unpublished).

Comas-Rengifo, M.J. \& Goy, A. 1975. Estratigrafía y paleontología del Jurásico de Ribarredonda (Guadalajara). Estudios Geológicos, 31, 297-339.

Comas-Rengifo, M.J. \& Goy, A. 1978. El Pliensbachiense y Toarciense en la Rambla del Salto (Sierra Palomera, Teruel). In: Grupo Español del Mesozoico. Jurásico de la Cordillera Ibérica (Extr. Guía de Excursiones), IV, $11 \mathrm{pp}$.

Comas-Rengifo, M.J., Goy, A. \& Yébenes, A. 1988. El Lías en el sector suroccidental de la Sierra de la Demanda (Castrovido, Burgos). Ciencias de la Tierra. Geología, $11,119-138$

Comas-Rengifo, M.J., Gómez, J.J., Goy, A., Arias, C., Bernad, J., García Joral, F., Herrero, C., Martínez, G. \& Perilli, N. 1996. The Toarcian in the Rambla del Salto (Sierra Palomera) section. In: 1st Toarcian and 4th Aalenian Working Group Meeting - Fieldtrip Iberian Range, GuideBook (coord. Ureta, S.). Universidad Complutense de Madrid, 27-48.

Donovan, D.T. 1962. New information on the Toarcian ammonite genus Pseudolillia Maubeuge 1949. Palaeontology, 5, 86-92.

Elmi, S. \& Rulleau, L. 1990. Le genre Pseudolillia (Ammonitine, Grammoceratinae) dans la Toarcien Superiéur (France, Spagne, Portugal, Maroc). In: Fossili, Evoluzioni e Ambiente. Atti del Secondo Convegno Internazionale, Pergola Ottobre 1987 (eds Pallini G., Cecca F., Cresta S. \& Santantonio, M.). Editore Comitato Centenario R. Piccinini, Ostra Vetere, 291-305.

Elmi, S., Goy, A., Mouterde, R., Rivas, P. \& Rocha, R. 1989. Correlaciones bioestratigráficas en el Toarciense de la Península Ibérica. Cuadernos de Geologia Ibérica, 13, 265-277.

Elmi, S., Gabilly, J., Mouterde, R., Rulleau, L. \& Rocha, R. 1994. L'étage Toarcien de l'Europe et de la Tethys; divisions et correlation. Geobios, 27, 149-159; doi: 10.1016/S0016-6995(94)80135-5.

Elmi, S., Rulleau, L., Gabilly, J. \& Mouterde, R. 1997. Toarcien. In: Bioestratigraphie du Jurassique OustEuropéens et Mediterranéen: Zonations Parallèles et Distribution des Invértebrés et Microfossiles (eds Cariou, E \& Hantzperge, P.). Bulletin du Centre de recherches Elf Exploration Production, 17, 25-36.

Elmi, S., Mouterde, R., Rocha, R. \& Rulleau, L. 2007. Une sucession de reference pour le Toarcien Moyen et Supérieur: les "Margas calcárias de Sâo Giâo" dans les environs de Cantanhede (sous-bassin nord lusitanien, Portugal). Ciências da Terra, 16, 113-133.

Fauré, P. 2002. Le Lias des Pyrénées. Strata, 39, 1-761. 
Fernández-López, S. 1985. El Bajociense de la Cordillera Ibérica. Departamento de Paleontología. Universidad Complutense de Madrid. $850 \mathrm{p}$.

Fernández-López, S. 2000. Temas de Tafonomía. Departamento de Paleontología, Universidad Complutense de Madrid, $167 \mathrm{p}$.

Gabilly, J. 1976. Évolution et systématique des Phymatoceratinae et des Grammoceratinae de la región de Thouars. Mémoire de la Societé Géologique de France, 124, 1-196.

Gabilly, J., Elmi, S., Mattei, J. \& Mouterde, R. 1971. Les zones du Jurassique en France. Toarcien. Comptes rendus sommaires de la Société géologique de France, 2, 82-84.

García-Gómez, R. \& Rivas, P. 1980. El género Pseudolillia en las Cordilleras Béticas. Cuadernos de Geología Ibérica, 11, 195-207.

García Joral, F., Gómez, J.J. \& Goy, A. 2011. Mass extinction and recovery of the Early Toarcian (Early Jurassic) brachiopods linked to climate change in Northern and Central Spain. Palaeogeography, Palaeoclimatology, Palaeoecology, 302, 367-380; doi: 10.1016/j.palaeo.2011.01.023.

Gèczy, B. 1985. Toarcian Ammonite Zones in the Gerece Mountain, Hungary. International Symposium on Jurassic Stratigraphy (Erlangen, 1984). Geological Survey Denmark, 1, 218-226.

Golonka, J. 2007. Late Triassic and Early Jurassic palaeogeography of the world. Palaeogeography, Palaeoclimatology, Palaeoecology, 244, 297-307; doi: 10.1016/j.palaeo.2006.06.041.

Gómez, J.J. \& Goy, A. 2004. Jurásico Inferior de las Cordilleras Ibérica y Costero-Catalana. In: Geología de España (ed. Vera, J.A.). SGE-IGME, Madrid, 495-500.

Gómez, J.J. \& Goy, A. 2005. Late Triassic-Early Jurassic palaeogeographical evolution and depositional cycles of the Western Tethys Iberian platform system (Eastern Spain). Palaeogeography, Palaeoclimatology, Palaeoecology, 222, 77-94; doi: 10.1016/j.palaeo.2005.03.010.

Gómez, J.J., Comas-Rengifo, M.J. \& Goy, A. 2003. Las unidades litoestratigráficas del Jurásico Inferior de las Cordilleras Ibérica y Costero Catalana. Revista Sociedad Geológica de España, 16, 227-237.

Goy, A. 1974. El Lías de Rama Castellana de la Cordillera Ibérica. Ph.D. Thesis, Universidad Complutense de Madrid (unpublished, 940 pp.). Abstract: Publicaciones del Departamento de Paleontología. Universidad Complutense de Madrid, 14, 1-35.

Goy, A. \& Martínez, G. 1990. Biozonación del Toarciense en el sector central de la Cordillera Ibérica. Cuadernos de Geología Ibérica, 14, 11-53.

Goy, A., Gómez, J.J. \& Yébenes, A. 1976. El Jurásico de la Rama Castellana de la Cordillera Ibérica (Mitad Norte). Unidades litoestratigráficas. Estudios Geológicos, 32, 391-423.

Goy, A., Jiménez, A., Martínez, G. \& Rivas, P. 1988. Difficulties in correlating the Toarcian ammonite succession of the Iberian and Betic Cordilleras. $2^{\text {nd }}$ International Symposium on Jurassic Stratigraphy (eds Rocha, R.B. \& Soares, A.F.). Lisboa, 155-178.
Goy, A., Martínez, G. \& Ureta, S. 1994. El Toarciense de la región de Pozazal-Reinosa (Cordillera Cantábrica, España). Coloquios de Paleontología, 46, 93-127.

Goy, A., Martínez, G. \& Ureta, S. 1995. Ammonitina (Hammatoceratidae) of the Toarcian and Aalenian in the Serra de Llevant (Isle of Mallorca, Spain). Hantkeniana, 1, 97-104.

Goy, A., Martínez, G., Arias, C., Bernad, J., García Joral, F., Gómez, J.J., Herrero, C., Perilli, N. \& Ureta, S. 1996. The Toarcian in the sector located between La Almunia de Doña Godina and Ricla. In: 1st Toarcian and 4th Aalenian Working Group Meeting - Fieldtrip Iberian Range, GuideBook (coord. Ureta, S.). Universidad Complutense de Madrid, 3-23.

Goy, A., Comas-Rengifo, M.J., Gómez, J.J., Herrero, C., Suárez Vega, L.C. \& Ureta, S. 2010. In: Biohorizontes de ammonoideos del Toarciense en Asturias. Comunicaciones del V Congreso del Jurásico de España. Museo del Jurásico de Asturias (MUJA), Colunga (eds Rúiz Omeñaca, J.J., Piñuela, L. \& García-Ramos, J.C.). Museo del Jurásico de Asturias, 94-102,

Guex, J. 1975. Description biostratigraphique du Toarcien supérieur de la bordure sud des Causses. Eclogae Geologicae Helvetiae, 68, 97-129; doi: 10.5169/ seals-164380.

Howarth, M.K. 2013. Mollusca 4, Part L (Revised), Volume 3B, Triassic and Jurassic Ammonoidea. In: Treatise on Invertebrate Paleontology Online (ed. Selden, P.A.). Paleontological Institute. University of Kansas Press, $139 \mathrm{pp}$.

Hyatt, A. 1867. The fossil Cephalopoda of the Museum of Comparative Zoology. Bulletin of the Museum of Comparative Zoology, 5, 71-102.

Kovács, Z. 2013. Grammoceratinae (Ammonitina) fauna a Gerecse hegységböl. Földtani Közlöny, 143, 123-143.

Martínez, G. 1986. El Toarciense en el sector comprendido entre La Almunia de Doña Godina y Ricla (Prov. de Zaragoza). Paleontología (Ammonoidea) y bioestratigrafía. M.Sc. Thesis, Universidad Complutense de Madrid (unpublished).

Martínez, G. 1992. Hammatoceratinae (Ammonitina) del Toarciense superior y Aaleniense en la Cordillera Ibérica. Ph.D. Thesis, Universidad Complutense de Madrid, Colección Tesis Doctorales UCM, 374/92, 1-331.

Martínez, G. 2007. Apthychus de Oxyparoniceras (Oxyparoniceras) buckmani (Bonarelli, 1895) (Paroniceratinae, Ammonoidea) del Toarciense de Ariño (Cordillera Ibérica, España). Coloquios de Paleontología, 57, 15-2.

Maubeuge, P.L. 1949. Notes paléontologiques sur quelques ammonites jurassiques, rares ou nouvelles de la région frontière franco-luxembourgeoise et de la Lorraine centrale. Archéologique Institut Grand-Duché du Luxembourg, 18, 149-178.

Metodiev, L. 2008. The Ammonite zones of the Toarcian in Bulgaria - New evidence, subzonation and correlation with the standard zones and subzones in North-Western 
Europe. Comptes rendus de l'Académie bulgare des sciences, 61, 87-132.

Monestier, J. 1921. Ammonites rares ou peu connues et ammonites nouvelles du Toarcien supérieur du SE de l'Aveiron. Mémoire de la Societé Géologique de France, $54,1-44$.

Mouterde, R. \& Elmi, S. 1991. Caractères différentiels des faunes d'ammonites du Toarcien des bordures de la Tethys. Signification paléogéographique. Bulletin de la Société géologique de France, 162, 1185-1195.

Mouterde, R., Fernández-López, S., Goy A., Linares, A., Rivas, P., Ruget, C. \& Suárez Vega, L.C. 1978. El Jurásico en la región de Obón (Teruel). In: Grupo Español del Mesozoico. Jurásico de la Cordillera Ibérica (Extr. Guia de Excursiones), II, $13 \mathrm{pp}$.

Mouterde, R., Rocha, R., Elmi, S., Ruget, C., Alméras, Y. \& Rulleau, L. 1998. Eléments biostratigraphiques pour le Toarcien moyen et supérieur de Sao Giao (Cantanhede, Portugal). Comunicações do Instituto Geológico e Mineiro, 84, A.57-A.59.

Page, K.N. 2003. The Lower Jurassic of Europe: its subdivision and correlation. Geological Survey Denmark and Greenland Bulletin, 1, 23-59
Reynès, P. 1868. Essai de Géologie et de Paléontologie Aveyronnaises. Ballières Ed., París, 109 pp.

Robles, S., Quesada, S., Rosales, I., Aurell, M., Meléndez, G. \& Bádenas, B. 2003. Jurassic: Basque-Cantabrian basin. In: The Geology of Spain (eds Gibbons, W. \& Moreno, M.T.). Geological Society, London, 215-223.

Rulleau, L. 1989. Les Grammoceratinae (Hildocerataceae, Ammonitina) du Toarcien supérieur de la región lyonnaise. Ph.D. Thesis, Université Claude Bernard-Lyon I, 187 pp.

Rulleau, L. 1994. L'évolution des Grammoceratinae (Hildocerataceae, Ammonitina) au Toarcien supérieur, dans la région lyonnaise. Geobios, 15, 331-339; doi: 10.1016/S0016-6995(06)80387-6.

Sassaroli, S. \& Venturi, F. 2005. The genus Pseudolillia (Maubeuge, 1949) (Ammonitina, Grammoceratinae) in the upper Toarcian of the central Apennines (Cingoli, Macerate, Italy). Bollettino della Società Paleontologica Italiana, 44, 231-236.

Suárez Vega, L.C. 1974. Estratigrafía del Jurásico en Asturias. Cuadernos de Geología Ibérica, 3, 1-369.

Ureta, M.S. 1977. El Toarciense terminal y el Aaleniense en la Sierra de la Demanda: Bioestratigrafía y Paleontología. M.Sc. Thesis, Universidad Complutense de Madrid (unpublished). 
